NBER WORKING PAPER SERIES

\title{
DOES CORPORATE OWNERSHIP MATTER? SERVICE PROVISION IN THE HOSPITAL INDUSTRY
}

\author{
Jill R. Horwitz \\ Working Paper 11376 \\ http://www.nber.org/papers/w11376 \\ NATIONAL BUREAU OF ECONOMIC RESEARCH \\ 1050 Massachusetts Avenue \\ Cambridge, MA 02138
}

May 2005

I thank Allan Brandt, Suzanne Cooper, David Cutler, Karen Eggleston, Don Herzog, Jim Hines, Mary Beth Landrum, Barbara McNeil, Ellen Meara, Nolan Miller, Martha Minow, Carl Morris, Joseph Newhouse, Ted Parson, Jon Skinner, Richard Zeckhauser, and seminar participants at the National Bureau of Economics, Harvard University Program in Health Policy, Harvard Center for Ethics and the Professions, Hauser Center for Nonprofit Organizations, and faculty seminars of the Detroit College of Law, Berkeley Graduate School of Public Policy, and University of Pittsburgh Graduate School of Public Health. Jia-Jia Ye and Austin Nichols provided excellent research assistance. I also thank Bonnie Burns from the Pusey Library map collection at Harvard University, Elizabeth Vigdor Richardson for sharing data, and Paula Payton for administrative assistance. Funding from the Harvard PhD Program in Health Policy, Harvard Center for Ethics and the Professions, Hauser Center for Nonprofit Organizations, National Institutes on Aging through Grant Number T32-A600186 to the National Bureau of Economic Research, and University of Michigan Law School John M. Olin Center for Law and Economics is gratefully acknowledged. The views expressed herein are those of the author and do not necessarily reflect the views of the National Bureau of Economic Research. The views expressed herein are those of the author(s) and do not necessarily reflect the views of the National Bureau of Economic Research.

(C)2005 by Jill R. Horwitz. All rights reserved. Short sections of text, not to exceed two paragraphs, may be quoted without explicit permission provided that full credit, including $\odot$ notice, is given to the source. 
Does Corporate Ownership Matter? Service Provision in the Hospital Industry

Jill R. Horwitz

NBER Working Paper No. 11376

May 2005

JEL No. I1, L3, L2

\begin{abstract}
Three types of firms - nonprofit, for-profit, and government - own U.S. hospitals, yet we do not know whether ownership results in the specialization of medical service provision. This study of over 30 medical services in urban, general hospitals (1988-2000) shows that ownership types specialize in medical services according to the profitability of those services. The paper examines three theories to explain the differences: 1) objectives, 2) capital prices, and 3) market characteristics. The findings are best explained by differences in the objectives adopted by hospital types rather than differences in capital constraints faced by them. Preliminary evidence suggests that hospital behavior depends on the ownership form of neighboring hospitals.
\end{abstract}

Jill R. Horwitz

University of Michigan Law School

625 South State Street

Ann Arbor, MI 48109-1215

and NBER

jrhorwit@umich.edu 


\section{Introduction}

The question of whether nonprofit firms differ from their for-profit counterparts has presented a persistent puzzle for law and economics. The hospital industry, in which for-profit, nonprofit, and government owned organizations operate side by side, has proved fertile ground for study. Though the empirical evidence has been mixed, much of the research on hospitals has found behavioral similarities. This is not surprising. Given that these organizations have so much in common - they all offer medical care, use similar resources, operate under the same healthcare regulations, employ doctors and nurses who are trained in the same institutions - one would expect a convergence of behavior, if not firm types.

The empirical results presented here are both new and surprising. Like previous studies, this paper asks whether hospital types behave differently. Yet, previous research has focused primarily on financial measures such as differences in costs, profits, billing, the value of uncompensated care, and responsiveness to financial pressure (for review see Sloan, 2000). Studying financial behavior yields an incomplete picture of hospital ownership. Scholarship on medical care and ownership has generally considered single medical interventions. Here, I examine whether and how organizational ownership is correlated with offering over thirty hospital services (see Table 1 for service list). I find strikingly large behavioral differences.

The results can be profitably used to examine economic theories on legal ownership. Here I explore three categories of theories: 1) "objectives theories" that maintain objective functions differ by ownership; 2) "capital prices theories" that maintain differences in capital sources constrain firm types to behave differently; 3) "market theories" that suggest firms respond to the ownership form of their competitors in the same market. 
I conclude that differences in firm objective functions better explain the behavioral differences identified here than do differences in capital costs. For-profit hospitals are more profit-seeking than either nonprofit or public hospitals. Government hospitals aim to provide needed, but unprofitable, goods to a greater degree than the other types. Nonprofit hospitals are often in the middle. To some extent, like for-profits, they pursue profits through offering profitable services and avoiding unprofitable services; to some extent, like public institutions, they provide for the public need by offering unprofitable, undersupplied services. Further, the results suggest that nonprofit objectives may not be robust to competitive pressures since the ownership status of a hospital's neighbors is correlated with its own medical service offerings. Identifying differences among ownership types is of practical consequence, both because of their potential relationship to health outcomes and the money at stake. Expenditures on hospital care were $\$ 486.5$ billion dollars (almost 5 percent of GDP) in 2002, and the average annual percentage growth rate is back on the rise (Heffler et al., 2004). To justify -- or condemn -- the billions of public dollars that are spent on nonprofit tax-exemptions and other subsidies we need to know how these public resources are used. While policymakers care a great deal about corporate ownership, taxation regimes and regulatory approaches have been mixed (for summary see Horwitz, 2003).

The remainder of the paper is organized as follows. Section II summarizes contending models of firm ownership. Section III presents the data and the empirical framework. Results are presented in Section IV, and alternative explanations and sensitivity tests are presented in Section V. Section VI concludes. 


\section{Nonprofit Hospital Behavior: Theories and Evidence}

Economists, health services researchers, and legal commentators have long debated the question of whether corporate ownership results in behavioral differences and why. Ownership models can be categorized into three groups - objective function theories, capital constraint theories, and market interaction theories.

\section{A. Objectives}

The primary theory of ownership status is that for-profits are profit-maximizers. Compared to other firm types, they are most likely respond to incentives (Danzon, 1982). For example, they may avoid low-paying patients by differentially locating near hospitals of last resort (Barro, 1998) or up-coding to generate higher reimbursements (Silverman and Skinner, 2000). There is some evidence that for-profits have had the most success at profit-making. At least during the 1990s, for-profit hospital margins were greater than those of government and nonprofit hospitals (Frank and Salkever, 2000). On the contrary, some have claimed no difference in objectives (Malani and Choi, 2004). Empirical studies have found little difference regarding hospital costs (Sloan et al., 2001, Snail and Robinson, 1998), the exercise of market power (Gaynor and Haas-Wilson, 1999), the adoption of technology (Sloan, Picone, Taylor Jr. and Chou, 2001), or responsiveness to legislation rewarding charity care (Duggan, 2000).

At least relative to for-profits, nonprofit and government hospitals may prioritize goals other than profit-making. (but see Danzon, 1982). Government hospitals, many of which descend from almshouses, are required by the agencies that control them to serve the poor (Altman and Henderson, 1989). Duggan (, 2000), for example, has found few barriers between 
government hospitals in California and controlling public entities, which reduced public subsidies in response to hospital revenue increases.

According to most objectives theories, nonprofits, despite being private entities like forprofit firms, are more likely than for-profits to adopt public goals. For example, they may differentially respond to private (Salamon, 1987) and public (Weisbrod, 1988) market failures in serving the needy, or maximize quality and quantity over profits (Newhouse, 1970). Rather than specifying the content nonprofit objective functions, however, most theorists have identified the mechanisms that cause nonprofits to adopt unique objectives. First, legal constraints, such as the non-distribution constraint imposed by federal and state tax law (Hansmann, 1980) or charitable trust and corporations law (Horwitz, 2003), may both encourage, or even force, nonprofit hospitals to maximize non-financial ends, and signal those ends.

Second, managerial behavior may differ among organizations. Perhaps because they are not evaluated according to the profits they generate, managers guide firms in seeking rewards based on criteria like quantity and quality (Newhouse, 1970). Alternatively, the form may attract special kinds of people. These could be managers who wish to commit to donor preferences for non-contractible aspects of quality (Glaeser and Shleifer, 2001) or those who hold particularly altruistic goals (Rose-Ackerman, 1996), such as a desire to cross-subsidize (James and RoseAckerman, 1986). Others suggest that the nonprofit form allows consumers to control the mission of the institution directly (Ben-Ner, 1983, Ben-Ner and Gui, 1993, James and RoseAckerman, 1986). Young (1981) outlines models in which physicians sort into different hospitals, types of hospitals, or regions according individual preferences for philanthropic behavior, among other preferences. That total monetary compensation of top hospital employees is substantially higher in for-profit than not-for-profit hospitals lends support to this theory 
(Roomkin and Weisbrod, 1999). A third and less benign theory of nonprofit objectives suggests that employees, through physician cartels, capture nonprofit hospitals and meet their personal interests through them (Pauly and Redisch, 1973).

\section{B. Capital Price Constraints}

It may be that external financial constraints, rather than objectives that are adopted by special kinds of organizations or the type of managers who choose to constrain themselves, cause firm behavior. Because hospital types raise capital from different sources, they face different capital costs (Gentry, 2002). The simple capital price theory that I consider follows from this observation. One variant is that for-profit hospitals face lower costs of capital than do nonprofit hospitals. The idea is that for-profit hospitals can respond to demand for services more quickly than other corporations because equity financing is more readily available and less cumbersome to manage than debt financing (Hirth, 1999). In the 1990s, over $\$ 100$ billion was invested in health care stocks (Manning, 1997), suggesting that it was easy for for-profit hospitals to raise capital (Blecher, 1997). Further, for-profit hospitals may have more flexibility in timing expenses because they may reinvest capital in hospital operations rather than paying interest. In fact, some hospitals that have converted from nonprofit to for-profit form explain the change as an attempt to obtain needed capital for operations as well as new equipment and buildings (Cutler and Horwitz, 2000). An implication of this view is that for-profit hospitals should show greater response to demand for capital-intensive services than other types of hospitals and, therefore, should have higher levels of investment in such services.

A contrary variant of the capital price theory proposes that for-profit firms are constrained in investment relative to nonprofits because they face higher costs of capital. Nonprofit hospitals 
have several advantages unavailable to for-profits. For example, they may issue more forms of tax-exempt debt than for-profits ${ }^{1}$ and may receive tax-exempt, tax deductible donations. In addition, for those nonprofit hospitals with endowments, borrowing tax-exempt debt and some amounts of taxable debt ${ }^{2}$ generates a tax arbitrage unavailable to for-profit hospitals (Gentry, 2002, Wedig et al., 1996). Empirical evidence demonstrates that nonprofit hospitals had a lower cost of capital than did for-profit hospitals during the 1970s, although the relationship reversed during the early 1980s (Wedig et al., 1989). An implication of this view is that for-profit hospitals should show greater response to demand for capital-intensive services than other types of hospitals and, therefore, should have higher levels of investment in such services. Regardless of which view is correct, if capital prices drive investment decisions, hospitals types should show different patterns of investment in expensive technology.

\section{Market Effects}

A third theory explaining differential firm behavior is that firms are influenced by the ownership status of their neighbors, either through influencing the choice of objectives or constraining behavior through competition, though the direction of the influence has been debated. Hansmann (1980) reasons that the presence of nonprofit firms will deter profiteering among for-profit health firms, while Cutler and Horwitz (2000) hypothesize that nonprofit and

\footnotetext{
${ }^{1}$ The relative cost of capital is a complicated issue. For example, for-profit hospitals borrow more than do nonprofit hospitals and, after accounting for tax deductions, taxable debt can represent a less expensive source of capital than tax-exempt debt (Frank and Salkever, 1994).

${ }^{2}$ Regulations limit the uses of tax-exempt debt available to nonprofit firms. Nonprofits, for example, must use taxexempt debt proceeds on physical assets. Between 1986 and 1997 there was a \$150 million limit on outstanding non-hospital, tax-exempt debt. (Gentry, 2002)
} 
government hospitals copy the behavior of new for-profit entrants in a hospital market. Others contend that there should be no influence of for-profits on nonprofits or vice versa because, with higher operating costs and no endowments, for-profits are the marginal firm and, therefore, are the only institutions responding to market changes (Lakdwawalla and Philipson, 1999).

There are few empirical studies that test the market effects theories. Silverman and Skinner (2000) show not only that for-profit hospitals up-code to generate revenues more than other types, but that in heavily for-profit markets, nonprofit hospitals up-code at similar rates as for-profit hospitals. Duggan (2000) demonstrates that nonprofit hospitals that faced for-profit competition were more likely than other nonprofits to respond to financial incentives to treat Medicaid patients under the California Disproportionate Share Program. In a case study, Cutler and Horwitz (2000) find that nonprofit hospitals adopt the billing procedures of for-profit hospitals in the same markets.

\section{Data and Methodology}

\section{A. Data}

Hospital data are from the American Hospital Association's Annual Surveys of Hospitals (AHA), years 1988 - 2000. Demographic data are from the 1990 U.S. Census. The sample includes all non-rural, acute-care hospitals that operate in Metropolitan Statistical Areas (MSAs) with at least two general medical and surgical hospitals, excluding military, uncategorized federal, and prison hospitals. I excluded rural hospitals because there are relatively few rural, for-profit hospitals and they provide a limited range of services. In 1995, for example, of the roughly 2,500 rural hospitals, only slightly more than 8 percent were for-profit and only a handful provided open-heart surgery. 
As Table 3 shows, over the study period slightly fewer than two-thirds of all hospitals were nonprofit, with for-profit and government hospitals making up roughly equal shares of the remainder. These shares were relatively stable over time. While there were conversions of hospitals from one form to another, the net flows were much smaller than the gross flows. The total number of hospitals fell over the time period.

I included all acute care services in the AHA surveys, with the exception of a small number for which the data were incomplete or the definition was too imprecise or inconsistent over the relevant time period to make valid comparisons. (See Table 1). The AHA data include variables for services provided, number of beds, ownership status, teaching status, admissions, and location. (See Table 4).

The AHA data have limitations. First, the data are self-reported and not independently verified. However, there is no a priori reason to suspect that data reliability is correlated with ownership. Second, the format of the survey changed slightly over the years. Hospitals were asked to choose whether a specific service (e.g. emergency department) was offered at the hospital, another hospital, or not available (1988-1993) or to answer "yes" if the service was offered at a hospital or subsidiary, as opposed to another location in the system, network, or joint venture (1994-2000). Because I am interested in hospital-based activities, I recoded the first category in each year as "yes," all other categories as "no," with a separate category for nonrespondents.

Finally, the data suffer from missing-values, particularly in the later years. Almost 20 percent of hospitals did not respond to the AHA survey and the non-respondents were disproportionately for-profit. Of the sample used in this study, in 1988 approximately 3 percent of nonprofit, 4 percent of government, and almost 18 percent of for-profit hospitals did not report 
whether they offered emergency services. By 2000, those percentages were about 14 percent for nonprofit, 20 percent for government, and 26 percent for for-profit hospitals.

When hospitals did not report whether they offered a service, I imputed the values using data from the years before and after the missing year. For the end years (1988 and 2000) I imputed a value based on whether the hospital offered the service for the next or previous two years. Where several years of values were missing, I excluded the observation from the analysis. Generally, fewer than 4 percent of observations were imputed for each service.

\section{B. Methodology}

I examine over thirty medical services singly to test whether individual service offerings differ by hospital ownership. To assess the alternative explanations for offering patterns, I group the services. First, to test the objectives theory, I examine whether hospital types differ in their likelihood of investing in profitable services, unprofitable services with high public need, and services with variable profits. Second, to test the capital prices theory I examine whether different hospital types are more or less likely to offer services with high start-up costs and whether those differences narrow over time. Finally, I investigate whether hospital types behave differently in markets with high for-profit hospital penetration. Table 2 illustrates the behavior predicted by each of the theories. 


\section{i. Objectives and Constraints}

To test my predictions, I estimated the following model: ${ }^{3}$

$\operatorname{Probit}(\operatorname{Prob}(\text { Service }))_{\mathrm{it}}=\beta_{\mathrm{o}}+\beta_{1}$ Form $_{\mathrm{it}}+\beta_{2}$ Year $_{\mathrm{t}}+\beta_{3}$ Year $_{\mathrm{t}}^{*}$ Form $_{\mathrm{it}}+\beta_{4} \mathrm{H}_{\mathrm{it}}+\beta_{5} \mathrm{D}_{\mathrm{i}}$

where FORM is a dummy variable for nonprofit, for-profit, or government ownership; Year is a year dummy variable; $\mathrm{H}$ are hospital characteristic variables including hospital size (measured as quartiles of admissions), teaching status (measured by teaching association membership), and a dummy variable for location by region in the country; D are demographic variables of the hospital's vicinity (including percentages of the population by sex, white or African-American race, $\ln$ household income, age categories $(<1,1-18,18-30,30-40,40-50,50-65,>=65,>=80)$ ). These were compiled from 1990 Census data arranged by aggregating census block groups that fell within a 10-mile radius of the center (by longitude and latitude) of the zip-code where the hospital operated. This distance is commonly used in the literature, and 10.4 miles is the mean distance radius that captures 75 percent of discharges from acute care hospitals in urban settings (Gresenz et al., 2004).

Because the probability of a hospital offering a service is not independent from one year to the next, I allowed for an arbitrary covariance matrix within each hospital over time. I also adjusted the models for heteroskedasticity. By varying only the corporate form of the hospital while holding the independent variables constant (at 1994 or next closest year levels), I predicted the probabilities that each hospital in each year would offer a given service. Then I averaged the

\footnotetext{
${ }^{3}$ One might think about using fixed effects to examine ownership, but doing so makes the estimation depend only on the experience of hospitals that switch form. The sample of switching hospitals is small and likely to be biased in ways that are correlated with service offerings. For example, money-losing hospitals are more likely to change form and also to forgo investment in services, plant, and equipment.
} 
individual predicted probabilities to obtain the probability that a hospital type offers a service each year. Using the Probit model, I have assumed that the binary variable follows a binomial distribution.

Determining what observed behavioral differences demonstrate about corporate intention is more difficult than establishing these differences. Finding differences in behavior regarding one or two services, for example, would not provide enough evidence to infer motivation. However, by looking at many services, grouped by characteristics such as profitability, I am able to infer differences in objectives. If, for example, one type of hospital differentially offers many of the most profitable services and systematically avoids the services that are relatively unprofitable (e.g. those that are often provided to an underinsured patient pool) that hospital's behavior is more consistent with profit-seeking than the behavior of hospitals that provide money-losing services.

Profitability, however, is not an inherent attribute of medical services, but depends on institutional-specific factors such as management skills, case mix, and local input costs. Further, within a single hospital, costs and charges differ, discounts vary by individual payer, and allocation of joint costs blur the profitability picture. Despite these complications one can, however, reasonably compare the relative profitability of services defined as bluntly as they are in the AHA data.

I sorted the medical services into three profitability categories (those with high, low, and variable profitability) and then re-sorted the services according to the level of required initial investment. Categories, reported in Table 1, are based on an exhaustive study of the relevant peer-reviewed, academic literature (medical, business, finance, statistics, sociology, and public policy), interviews with hospital administrators, doctors, and policy-makers, and analyses of the 
socioeconomic or insurance status of patients likely to demand various services. Because Medicare payments are the largest single source of hospital revenues, I also analyzed the Medicare Payment Advisory Commission (MedPac) and Prospective Payment Assessment Commission (ProPAC) reports to Congress for the relevant years. Further, because this project is concerned primarily with hospital behavior and motivation, I checked the published, scientific literature with a comprehensive review of trade publications, business magazines, and newspaper reports. The qualitative evaluation of relative service profitability was critical to the project because perceptions of whether a service would be profitable were likely as, possibly more, important determinants of service investment choices than whether services turned out to be profitable. Regardless, there was little disagreement among these sources. A full report is available online (Horwitz, 2005).

Highly Profitable Services Many of these services, such as cardiac care, are predominantly provided to older patients, patients who are insured through Medicare; during the early to mid-1990s, Medicare had a generous payment schedule relative to other types of insurance (Grossman, 2002). By testing whether hospital types differentially provide services according to relative profitability, I am able to determine the relative degree to which the hospitals pursue profitability and, therefore, offer support for or against the objectives theory. The highly profitable services include angioplasty, birthing rooms, cardiac catheterization, diagnostic imagining equipment (computed-tomography scanner -- CT, diagnostic radioisotope facility, magnetic resonance imaging -- MRI, positron emission tomography -- PET, single photon emission computed tomography -- SPECT, and ultrasound), extracorporeal shock-wave lithotripter (ESWL), fitness center, neonatal intensive care, open heart surgery, pediatric intensive care, sports medicine, and women's centers. 
Relatively Unprofitable Services for Needy Patients The services in this category often answer public need, yet they are expensive to provide compared to available reimbursement or patient payments. With the exception of emergency care, ${ }^{4}$ hospitals are not required to offer these services. I examine these services to determine whether hospital types differentially offer services that provide community benefits without the prospect of high profit. Analyzing this group of services also helps evaluate one form of the objectives theory, one under which nonprofit and public hospitals have goals of altruism or meeting public need. In this category, I include AIDS/HIV services (outpatient, testing, general services, special unit), alcohol and substance abuse inpatient and outpatient care, burn treatment, child and adolescent psychiatric services, emergency rooms, obstetrics services (measured by beds and deliveries), inpatient adult psychiatric care, psychiatric emergency services, and trauma centers.

Services with Variable Profits This category of services, services for which the opportunities for profit-making changed over the study period, includes the post-acute services skilled nursing and home health. This category is particularly useful for testing relative objectives since it shows how service provision tracks changes in profitability.

Capital Intensive Services The final group of services is those for which capital costs are relatively high. These include some diagnostic imaging equipment, cardiac services, birthing rooms, burn treatment, emergency rooms, ESWL, neonatal and pediatric intensive care, orthopedic surgery, and trauma centers. If capital constraints are operating on for-profit hospitals, nonprofit hospitals should invest in capital-intensive services more than do others.

\footnotetext{
${ }^{4}$ Approximately half of the states require hospitals to have emergency care facilities as a condition of licensure or funding (Showalter, 1999). And, hospitals must provide emergency care as a condition of participating in the
} 


\section{ii. Market Effects}

To test whether the mix of hospital types in a market affects individual hospital operations, I test the interaction between corporate form and market.

$$
\begin{aligned}
& \operatorname{Probit}\left(\text { Prob}_{(\text {Service })}\right)_{\text {it }}=\beta_{\mathrm{o}}+\beta_{1} \text { Form }_{\mathrm{it}}+\beta_{2} \text { Year }_{\mathrm{t}}+\beta_{3} \text { Year }_{\mathrm{t}}{ }^{*} \text { Form }_{\mathrm{it}}+\beta_{4} \text { Market }_{\mathrm{it}}+\beta_{5} \\
& \text { Form }_{\mathrm{it}} * \text { Market }_{\mathrm{it}}+\beta_{6} \text { Year }_{\mathrm{t}}{ }^{*} \text { Form }_{\mathrm{it}}{ }^{*} \text { Market }_{\mathrm{it}}+\beta_{7} \mathrm{H}_{\mathrm{it}}+\beta_{8} \mathrm{D}_{\mathrm{it}}
\end{aligned}
$$

where the market dummy variable identifies for-profit markets, defined as those metropolitan statistical areas (MSAs) in which for-profits represent more than a given percentage of admissions. As in model 1, the observations were clustered according to hospital identification number, and I have assumed that the binary variable follows a binomial distribution.

\section{Results}

This section presents the findings for services that are representative of the four types consistently profitable (open heart surgery), consistently unprofitable (psychiatric emergency), variably profitable (home health), and those with high capital costs (MRI and ESWL).

\section{A. Objectives Theories}

\section{i. Consistently Profitable Service: Open Heart Surgery}

Although I focus on open-heart surgery in this section, the results for cardiac catheterization labs and angioplasty are remarkably similar. Open heart surgery (coronary artery 
bypass graft or $\mathrm{CABG}$ ) refers to one of two revascularization procedures used to improve blood supply to the heart after a patient suffers a heart attack by splicing a piece of vein or artery from another part of the body around the blocked artery. Cardiac services -- including cardiac catheterization, angioplasty, and open-heart surgery - are, and are widely known to be, hospital profit centers (Stout, 2001, Wagner, 1991). During the study period, for-profit corporations opened single-service cardiac surgery centers, while neighboring hospitals expected to lose profitable business (Dang, 2002, Devers et al., 2003, Gallagher, 1998, Ginsburg, 2000, Meyer, 1998, Romano, 2004, Winslow, 1999).

There is considerable evidence that cardiac care's reputation as a money maker is justified. As surgical services, heart attack treatments are typically well-reimbursed by insurers (Brennan, 2002, Cutler et al., 2000). Since most are Medicare beneficiaries, patients receiving open-heart surgery are unusually well insured. Insurers typically reimburse heart attack treatments at high rates; patients receiving $\mathrm{CABG}$ are unusually well insured since most are covered Medicare; and, there is high and increasing spending on cardiac care (Cutler, McClellan and Newhouse, 2000). From 1984 to 1994, the real price for bypass surgery among Medicare patients increased by 2.3 percent annually from $\$ 29,176$ to $\$ 36,564$ (1991 dollars) while the share of patients receiving the treatment increased by one percentage point annually from 5 to 15 percent (Cutler et al., 2001). The costs of supplying CABG in real terms were either flat or fell during the same period (Cutler and Huckman, 2003). In 1991, because spending on bypass surgery was so high, the Health Care Financing Administration ran a pilot program in which hospitals and physicians negotiated bypass surgery prices (Cromwell et al., 1997).

Appendix A reports estimates from the basic specification of the probability of offering open heart surgery by ownership type, controlling for hospital and demographic characteristics. 
These results demonstrate that for-profits are more likely to offer open heart surgery than nonprofits, which in turn are more likely to do so than government hospitals. Specifically, the null hypotheses that for-profit, nonprofit, and government provision of open heart surgery are jointly equal ${ }^{5}$ to each other (the coefficients on the corporate form and corporate form * year interaction variables for one form are jointly equal to those of another form) can be rejected at the .01 level.

The magnitude of these differences is large. The differences can be seen best in Figure 1, which plots the Probit predicted probabilities of service offerings by hospital type, controlling for the hospital and demographic characteristics discussed above. For-profits are, on average, 13 percentage points more likely than government hospitals $(40.9 \%$ v. $27.9 \%, \mathrm{P}<0.001)$ and 7.3 percentage points more likely than nonprofit hospitals $(40.9 \%$ v. $33.6 \%, \mathrm{P}<0.001)$ to offer openheart surgery (See Table 7 for hypothesis tests).

Over the study period, the probability of offering open heart surgery increased for all three types of hospitals. Again, this is easiest to see in Figure 1. The relationship can also be seen by the positive, significant, and increasing coefficients on the year dummies, and the mostly small and insignificant coefficients on the year*gov and year*fp interactions, which indicate that the relationship between the forms remained stable over time (See Appendix A).

The pattern of service provision for open heart surgery supports the theory that the hospital types have different objectives. This evidence alone, however, does not help

\footnotetext{
${ }^{5}$ I conducted two sets of hypothesis tests: 1) tests on whether the coefficients on the corporate form and corporate form * year interaction variables for one form (e.g. for-profit) are jointly different those of another form (e.g. nonprofit) and 2) tests on whether the average of these coefficients are different among forms. These hypothesis tests, which I refer to as the Joint Tests and the Average Tests, are presented in Table 7.
} 
differentiate among two possible goals. For-profits may be more interested than other types in offering either all medical services or profitable services.

\section{ii. Consistently Unprofitable: Psychiatric Emergency}

Conversely, hospital-based, psychiatric emergency services are relatively unprofitable for several reasons. First, the emergency room is generally an unprofitable setting, which attracts patients whose admissions are relatively expensive (Deloitte \& Touche, 1990, Gentry and Penrod, 2000, Melnick et al., 1989). During the study period, many providers believed that emergency care was unprofitable, in part, because public reimbursement did not include additional payments for emergency care that precedes inpatient care and, therefore, did not cover costs such as licensing and standby costs (Eisenberg, 1990). Whether reimbursements are actually sufficient to cover the costs of emergency care prior to admission, however, depends on the total level of reimbursement for the admission.

Second, psychiatric care reimbursement is uncertain and often low relative to cost (Woodward et al., 1997). Psychiatric emergency patients are dominated by two groups of patients characterized as "bad payers" - the Medicaid population and the uninsured (Gottlieb, 2002). During the 1990s, both private and public payers sought methods to control mental health costs. State Medicaid programs facing budget shortfalls often cut mental health services, including services previously available in state psychiatric hospitals, to balance budgets (BNA Health Care Daily, 1995). The rapid expansion of mental health carve-out programs and other cost-control methods also led to low provider payments in private settings.

Third, mental health services attract a poor, poorly insured, sick, and difficult to manage population (Woodward, Epstein, Gfroerer, Melnick, Thoreson and Wilson, 1997). The patients 
that use psychiatric emergency care, for example, are particularly underprivileged (Dhossche and Ghani, 1998). Young adults, who are disproportionately uninsured are overrepresented as mental health patients, while the elderly, who are insured by Medicare, are underrepresented (Ellison et al., 1986). One studied demonstrated that mental health patients are disproportionately sick, uninsured, and difficult to manage (Shwed, 1980, Tye, 2001). Further, approximately 7 to 18 percent of psychiatric emergency patients and one-third of the visits are difficult-to-treat, repeat visitors with chronic conditions (Ellison, Blum and Barksy, 1986).

Finally, not offering psychiatric emergency capacity may protect hospitals from liability under the Emergency Medical Treatment and Labor Act (EMTALA). EMTALA requires hospitals that both have emergency rooms and serve Medicare beneficiaries to stabilize emergency patients, including emergency psychiatric conditions, ${ }^{6}$ before transferring them to another hospital. ${ }^{7}$ Emergency rooms, however, are only required to screen and stabilization patients with conditions that fall within the emergency room's capabilities. If a hospital does not offer psychiatric treatment or have mental health professionals on staff, EMTALA does not require it to stabilizing emergency psychiatric patients before transferring them, ${ }^{8}$ thus making it easier to transfer a class of poorly insured, high-risk patients.

Appendix A contains estimates from the basic specification. These results demonstrate that, unlike open heart surgery, for-profits are less likely than nonprofits, which in turn are less likely than government hospitals to offer this unprofitable service (See Figure 2). Specifically, the null hypotheses that, for all thirteen years, 1) for-profit and government hospitals and, 2)

\footnotetext{
${ }^{6}$ Psychiatric disturbances may constitute an emergency condition. 42 C.F.R. $§ 489.24(b)$ (i) (2000).

${ }^{7}$ Emergency Medical Treatment and Active Labor Act (EMTALA) 42 U.S.C.A. $§ 1395(d)(d)$.
} 
nonprofit and government hospitals are equally likely to offer the services can be rejected at the .001 level. The null hypothesis that the for-profit and nonprofit hospitals are jointly equal cannot be rejected (See Table 7).

On average from 1988 to 2000, 41 percent of for-profit hospitals were predicted to offer psychiatric emergency services, compared to 48 percent of nonprofit hospitals and 56 percent of government hospitals. The null hypotheses that these averages are equal can be rejected at the .001 level (See Table 7 for details). The magnitude of these differences is large - for-profits are 15 percentage points more likely to offer psychiatric emergency services than are government hospitals. This can be seen best in Figure 2, which plots the Probit predicted probabilities of offering psychiatric emergency care by hospital type.

In addition, the probability of offering psychiatric emergency services remained flat over time, and the relationship among types remained approximately constant. It is easiest to see this in Figure 2. The relationship can also be seen by the mostly small and insignificant coefficients on the year dummies and on the year*gov and year*fp interaction terms in Appendix A, which indicate that the relationships among hospital types remained stable over time.

The investment patterns for psychiatric emergency care also lend support to the objectives theory. Government hospitals appear relatively more willing to invest in a service that is needed by the public than are nonprofits which are, in turn, more willing to provide the service than are for-profit hospitals. This evidence, coupled with the evidence from open heart surgery, supports the view that hospital types differ according to their interest in pursuing profits rather than the

\footnotetext{
${ }^{8}$ Baker v. Adventist Health, Inc. 260 F.3d 987 (9 $9^{\text {th }}$ Cir. 2001).
} 
view that hospital types differ according to their interest in pursuing more or fewer services per se.

iii. Service with Variable Profitability: Home Health Care

Changes in the profitability of post-acute services, such as home health and skilled nursing, ${ }^{9}$ make them particularly useful services to test the relative responsiveness of hospitals to financial incentives in their service investments and, therefore, to infer the goals they pursue. With the implementation of the prospective payment system in 1984, post-acute services became very profitable. Unlike acute services payments for which hospitals receive a single per-episode payment for each patient, Medicare paid a cost-related reimbursement for post-acute services. For example, home health services were reimbursed according to cost, up to 112 percent of the national mean cost per visit (Newhouse, 2002b). In addition, the payment system was particularly generous to entrants, exempting skilled nursing facilities and home health services from cost limits for the first three to four years of operation (Newhouse, 2002a).

These generous reimbursements coupled with the fixed payment built into the Medicare payment system made post-acute services particularly valuable for acute care hospitals. Rather than receiving a single payment for an inpatient, hospitals could increase reimbursements by unbundling the services and transferring a patient to a post-acute bed at the end of their hospital stay. There is considerable evidence of these transfers. Between 1988 and 1996 acute care lengths of stay fell 27 percent for Medicare patients and only 15 percent for all patients; during

\footnotetext{
${ }^{9}$ I have eliminated rehabilitation services from the analysis because the AHA survey does not specify the rehabilitation unit type, which strongly affects service profitability.
} 
the same period post-acute service usage and payment rose rapidly (Newhouse, 2002b). Finally, the hospital could allocate joint costs to these units, increasing the total reimbursement to the hospital. The rapid increase in Medicare spending on and utilization of post-acute services reflects response to these incentives. Home health payments grew from $\$ 3.9$ billion to over \$18.3 billion between 1990 and 1996 (Liu et al., 1999). Although the incentives for providing post-acute services were in place in the early-1980s, it was not until the late 1980s that eligibility and coverage guidelines were clarified in federal court decisions. ${ }^{10}$

The potential profitability of these services was widely understood by hospital administrators, consultants, and regulators alike (Geriatric Health Ventures Incorporated, 1992, Helbing and Cornelius, 1992, Helbing et al., 1992, Scharmach, 1990, Wagner, 1989). One article in the trade press, for example, urged hospital administrators to view skilled nursing facilities as a "higher reimbursement category, not necessarily a geographic location" (Deangelis, 1987). In the early 1990s, regulators searched for solutions to contain post-acute service spending, which they believed was unnecessary (Vladeck and Miller, 1994). Observers predicted that these services would remain profitable even if capitated (1993, Fowler, 1992, Lutz, 1992, O'Donnell, 1993).

The profit-making opportunities of post-acute care plummeted with the 1997 Balanced Budget Act (BBA). Medicare payments were reduced, the Health Care Financing Agency developed a prospective payment system for post-acute services, and spending on home health care fell by a factor of two.

\footnotetext{
${ }^{10}$ Duggan v. Bowen 691 F.Supp. 1487 (1988), effective 1989, made patients who would be stabilized by home health services, in addition to patients who would be improved by the services, eligible for the services.
} 
Appendix A contains estimates from the basic specification. Not only did the probabilities of offering home health care vary by ownership, the relative differences among types varied over time. The probabilities of offering home health services when the service was profitable increased for all three hospital types. As can be seen in Figure 3, however, the growth of home health care when profitable and the decline when unprofitable among for-profit hospitals were particularly dramatic. From 1988 to 1996, the probability of a for-profit hospital offering home health services more than tripled (17.5 percent to 60.9 percent). During the same period, the probability of offering home health care only grew slightly over 10 percentage points (40.9 percent to 51.7 percent) for nonprofit and 14 percentage points (38.1 percent to 51.9 percent) for government hospitals.

From 1997 to 2000, as home health care became relatively unprofitable with the BBA's implementation, the probability of offering it fell a striking 37.5 percentage points among forprofits, 7.7 percentage points among nonprofits, and 1.5 percentage points among government hospitals. All relevant null hypotheses can be rejected at the 0.01 level. This finding provides important evidence regarding the magnitude (large) and speed (fast) of for-profit responsiveness to incentives.

\section{B. Capital Prices Theory}

This section discusses two representative services, Extracorporeal Shock Wave Lithotripsy (ESWL) and Magnetic Resonance Imagining (MRI), to test the capital constraint theory. In 1984, the Food and Drug Administration approved the use of Extracorporeal Shock Wave Lithotripters, machines that uses shock waves to shatter kidney stones or gallstones. Because the typical lithotripter costs about $\$ 1$ million, only approximately 240 hospitals in the 
country had them in the early 1990s but, in 1991, there were reports that a new, much less expensive machine was being developed (1991).

MRI allows technicians to determine tissue types by looking at a map of how hydrogen nuclei in different parts of the body respond to the magnetic field generated by the machine. Like all diagnostic imaging equipment, magnetic resonance imaging technology is very expensive; a typical machine, excluding installation and licensing fees, costs approximately $\$ 1.5$ million (Anonymous Interviewee, 2002).

Appendix A contains estimates from the basic specifications. Consistent with theories about technology diffusion, all types of hospitals were more likely to have MRIs and ESWLs over time. The patterns of adoption, however, were quite different. As can be seen most easily in Figure 4, for-profit hospitals were always more likely to offer ESWL services during the years studied. On average, 22 percent of for-profit hospitals, 17 percent of nonprofit hospitals, and 13 percent of public hospitals were likely to offer ESWL. These differences are significant at, at least, the 0.003 level (Table 7).

On the other hand, for-profits were only slightly more likely than nonprofit hospitals to have MRIs. On average, 51 percent of for-profit hospitals and 48 percent of nonprofit hospitals, controlling for hospital and demographic characteristics, were predicted to have MRIs. The difference is insignificant (See Table 7). Further, the relative probability of offering the service changed over time. Between 1988 and 1992, nonprofit hospitals were predicted to be more likely than for-profit hospitals to have MRIs; between 1993 and 1998, for-profits were more likely than nonprofits to offer the service. Government hospitals were, on average, approximately 7 to 10 percentage points less likely than either of the other types to offer MRI (See Figure 5). Neither of these services demonstrated either hypothesized pattern of the capital constraint theory -- a 
pattern of investment in which either for-profit or nonprofit hospitals consistently invest more in these services.

\section{Looking Across all the Technologies}

Table 5 summarizes the results for all tested services. Although for-profit hospitals were only somewhat more likely than nonprofits to offer profitable services, both for-profit and nonprofit hospitals were considerably more likely than government hospitals to offer profitable services. For-profits were less likely than nonprofits, which in turn were less likely than government hospitals, to offer unprofitable services. The objectives theory is further supported by the patterns of offering services with variable profits. As can be seen in Table 6, for-profits exhibited dramatic responsiveness to financial incentives, particularly in terms of investing in post-acute services as they became profitable and divesting from them as they became unprofitable.

The services examined in the study demonstrated neither pattern predicted by the capital prices theory. For-profits were less likely than nonprofits to have birthing rooms, a capital intensive service, during the early years of the study (in $1988 \mathrm{~F}=64 \% \mathrm{v}$. N=70\%), but by 2000 that gap shrank $(\mathrm{F}=75 \% \mathrm{v} . \mathrm{N}=77 \%)$. Government hospitals were less likely than the other types to have CAT scanners, another capital intensive service, during the early years of the study (e.g., in $1988 \mathrm{~F}=88 \%, \mathrm{G}=80 \%, \mathrm{~N}=87 \%)$, but by 2000 they were more likely to have them $(\mathrm{F}=93 \%$, $\mathrm{G}=96 \%, \mathrm{~N}=95 \%$ ). From these results it appears that access to equity capital did not lead forprofit hospitals to consistently make greater investments in expensive technology than nonprofits. (See Table 5, services with high initial capital needs in italics). Nor did access to 
tax-exempt debt, endowment, or tax arbitrage opportunities lead nonprofit hospitals to consistently make greater investments in expensive technology than for-profits.

\section{Market Results}

To appraise the market theory, I asked whether hospital types offered different services depending on the for-profit penetration in the local markets. To do this, I tested the interactions between ownership form and a dummy variable for for-profit markets, defined as metropolitan statistical areas with greater than or equal to 20 percent for-profit admissions. I chose this breakpoint because few hospitals operate in markets with higher for-profit penetration, though tests of markets with greater than or equal to 10 percent for-profit admissions on a more limited data set yielded similar results. Measured by the share of hospital admissions in an MSA, the mean for-profit share market share was 0.115 , the median was 0.045 , and the standard deviation was 0.149 .

The market regressions support the theory that hospitals, particularly for-profit and nonprofit hospitals, learn from or compete with neighboring hospitals. The results also support, albeit with limited evidence, the idea that nonprofit hospitals copy the profit-making techniques of their for-profit neighbors. Again, I focused on three representative services to determine whether hospital types offered different services in for-profit and other markets.

All hospital types were more likely to offer open heart surgery, a very profitable service, in markets with at least 20 percent for-profit market share than in other markets (See Appendix B and Figures 6, 7, 8). Nonprofit hospitals, for example, were on average 5.4 percentage points more likely to offer open heart surgery in markets with at least 20 percent for-profit penetration than in other markets (differences significant at 0.05 percent level, See Table 8 for hypothesis 
tests). For-profit and government hospitals followed a similar pattern, offering open heart surgery at a greater rate in for-profit markets than in other markets (See Figure 6). Although the results for for-profit hospitals were not statistically significant for the full study period, excluding the most recent two years of data (1999 and 2000), there were large and significant differences. At least for this profitable service, having for-profit neighbors matters.

The results for home health were similar for nonprofit hospitals. Nonprofit hospitals were more likely to offer home health in for-profit markets than in other markets during almost the entire period (See Figure 7). These results, coupled with open heart surgery, might seem to suggest that hospitals are more likely to offer all services in for-profit markets than in other markets. However, there is reason to reject this theory. First, though nonprofits were more likely to offer home health in for-profit markets throughout the study period, the largest gap came during the particularly profitable period for investment from 1993 through 1996. Further, forprofit hospitals were only more likely to provide home health in for-profit markets than in other markets during this profitable period (See Figure 8). There was no statistically significant difference between government hospitals in for-profit and other markets during this period.

On the contrary, on average over the thirteen years studied, for-profit hospitals were equally likely to offer psychiatric emergency services in both types of markets (See Figure 8). However, government hospitals were 4.6 percentage points more likely to provide psychiatric emergency care in for-profit markets than in others, although the difference was not statistically significant. Nonprofit hospitals were also 4.5 percentage points more likely to offer this unprofitable service and the results were statistically significant at the 0.10 level. Interestingly, during the later years of the study period, nonprofits in for-profit markets seem to be exiting the psychiatric emergency business. While from 1988 to 1993 there was little difference in the 
probability of offering the service in each type of market, from 1994 to 2000, nonprofits in forprofit markets were approximately 7.1 percentage points less likely to have the service than those in other markets. The null hypothesis that the probabilities were equal was rejected at the 0.05 percent level.

These results, coupled, with the results for open heart surgery, support the claim that nonprofit hospitals are influenced by the behavior of their for-profit neighbors. They are more likely to offer profitable services and less likely to offer unprofitable services in markets with relatively higher for-profit penetration.

\section{Alternative Explanations and Sensitivity Tests}

\section{A. Alternative Explanations}

There are two alternative explanations to the results, both raising potential endogeneity concerns with the model. First, as Wennberg (1999) and others have observed, medical service provision varies considerably by small geographic region. Norton and Staiger (1994) have further shown that relatively low uncompensated care provision at for-profit hospitals can be explained, in part, by location. Using a case study approach for three markets, McClellan and Staiger suggested that for-profit hospitals locate in areas with low hospital quality (McClellan and Staiger, 2000). One might think, therefore, that firm types pick small areas in which to operate based on the character of demand in those areas, such as patient demand or physician preference for open heart surgery or medical management. Where demand for profitable services is greatest, therefore, one would expect more for-profit firms than in other areas.

I tested this alternative explanation for the results by using a fixed-effects approach, including an indicator variable for the year 2000 Hospital Referral Regions (HRR) in which each 
hospital operates. The coefficient implications produced by additional analyses of the three representative services described above (open heart surgery, psychiatric emergency care, and home health care) remained the same. The relevant differences remained significant at the one percent level with one exception. The average difference between nonprofit and for-profit hospitals offering open heart surgery was significant at the one percent level, however tests for the joint difference lost significance.

These results are not only quantitatively reassuring; they make sense. First, medical services differ in important ways from uncompensated care, the good studied by Norton and Staiger in 1994. It is likely easier for hospitals to avoid locations in which there is likely to be considerable demand for uncompensated care than demand for a bundle of unprofitable medical services. In fact, the early wave of hospital purchases by for-profit chains were in relatively wealthy suburban areas, where there are comparatively few uninsured patients. To predict the demand for a large number of services, potential hospital purchasers would need to know details about patient population risk and insurance characteristics that are hard to find and, moreover, change over time. A much easier strategy for a hospital wishing to earn profits would be to limit offerings of unprofitable services. Second, based on how hospital conversion markets work, the objectives explanation is more plausible than the geographic selection story. For-profit chains have typically bought hospitals that were for sale, often because they were failing financially (Picone et al., 2002).

A second alternative explanation is that individual hospitals choose ownership form based on their financial status. Profitable hospitals choose for-profit status, unprofitable hospitals choose nonprofit status. This explanation, however, is at odds with conversion experience. Failing hospitals, not profitable hospitals, typically convert from nonprofit to for- 
profit status (Picone, Chou and Sloan, 2002). In addition, hospital reimbursement and financial margins are uncertain and fluctuate considerably over relatively short time periods (See, e.g., Commission, 2004). Even if hospitals could reasonably predict reimbursement and profitability, changes in ownership are costly in several respects. Legal permissions are difficult to secure and challenges likely, professional legal and consulting costs are high, and reputational effects can be large.

\section{B. Propensity Scores and Other Sensitivity Tests}

The results were robust to several other sensitivity tests on the three representative services. Because size is the best predictor of offering any service, I restricted the regressions to the observations in the top two quartiles, bottom two quartiles, and middle two quartiles of hospitals measured by number of admissions to the hospital. Restricting the tests to the smallest hospitals, those in the bottom two admissions quartiles, the finding that nonprofit hospitals were more likely than government hospitals to offer open heart surgery was not significant. This result is not surprising because so few small hospitals offer open heart surgery at all. Like open heart surgery, among the smallest hospitals, the finding that nonprofit hospitals were more likely than for-profit hospitals to offer psychiatric emergency services was not significant.

To test the sensitivity of the results to demographic characteristics, I added age-squared categories for percentage of the population over 65 years and over 80 years. Because state payment policies for mental health services vary considerably, I included state dummies and state-year interactions for the psychiatric emergency service probit estimations. To test variation within the government hospital category, I excluded veterans' hospitals. The probability that nonprofit and non-veteran government hospitals were equally likely to offer psychiatric 
emergency services could not be rejected at the 0.10 level. In addition, because firm types tend to cluster in different regions I altered the region variable to account for areas of high for-profit penetration (e.g. south ${ }^{11}$ and southwest ${ }^{12}$ ) and included dummy variables for all nine regions listed in the AHA dataset.

Finally, I reanalyzed the three services using propensity scores, a method used to make causal inferences when assignment to a group, such as corporate ownership, is not random (Rosenbaum and Rubin, 1983, 1984). This method allowed me to ensure that I had compared hospitals that differed primarily by ownership and not other characteristics such as hospital size. More specifically, I determined the conditional probability of corporate ownership (nonprofit v. for-profit; nonprofit v. government, government v. for-profit) given the observed characteristics used in the Probit estimates (the propensity scores), created five subcategories defined by the estimated propensity score, and predicted the probability of a hospital type offering a service in a given year controlling for the propensity grouping. These tests did not change the results reported above in any meaningful way. ${ }^{13}$ The null hypothesis that nonprofit and government hospitals were equally likely to offer open heart surgery could not be rejected at the 0.05 level $(\mathrm{p}=0.078)$.

\footnotetext{
${ }^{11}$ Southern region includes: Florida, Georgia, South Carolina, North Carolina, Arkansas, Louisiana, Tennessee, Alabama, Mississippi, and Kentucky.

${ }^{12}$ Southwestern region includes: Texas, New Mexico, Arizona, and Nevada.

${ }^{13}$ The predicted probabilities of offering a service were slightly different than those produced by the Probit tests because the predictions were generated only from subsets of the data (e.g. only nonprofits and for-profits; only public and nonprofits). The relationships among the hospitals, however, were consistent with the Probit results.
} 


\section{Conclusion}

The empirical findings - that different hospital types offer different services, varying systematically with their profitability - challenge an emerging view that there are few differences among the nonprofit and for-profit forms (Sloan, 2000). The magnitude and robustness of the findings are striking in themselves, particularly given the blunt nature of the dependent variables and hospitals' regulatory context.

Plausible ownership theories should account for all three firm types. These results undermine two reasonable hypotheses about behavioral differences. Neither (1) the divide between government and private (both for-profit and nonprofit) institutions, nor (2) the divide between profit-distributing and non-distributing (both nonprofit and government) institutions can explain the differences described here. Although nonprofits are similar to for-profit hospitals because they are both private entities, they differ in their responsiveness to incentives. Although nonprofits are similar to government hospitals because they are legally prohibited from distributing profits to owners, nonprofits are not substitutes for government hospitals in the provision of unprofitable services that are disproportionately demanded by needy patients.

The results also undercut the simple capital prices theory. There is no clear pattern that relative access or costs of capital constrain hospitals by type. More work on the question, however, is needed. These results may be because there are many factors that contribute to the decision and ability to invest in technology, capital costs only representing one. Licensing requirements under certificate-of-need programs, for example, could prevent hospitals from investing in a service despite easy access to low cost capital. Or, differences in the sources of capital may be over estimated. With increasing hospital consolidation and the growth of hospital chains, nonprofit hospitals may operate internal capital markets that make them more similar to 
for-profit capital markets than this theory suggests. Likewise, the greater flexibility of equity capital may also be overestimated since, for example, for-profits may issue certain forms of taxexempt debt and nonprofits have access to flexible funds such as endowment (Frank and Salkever, 2000, 1994).

In light of this evidence, the objectives theories seem more plausible than the capital prices theories. Although specifying non-financial objective functions is difficult, the evidence bolsters the theory that government hospitals are hospitals of last resort. They are more likely than other types to offer unprofitable services that are generally needed by poor, underinsured patients. Nonprofit hospitals are the intermediate type. They are less responsive to financial incentives than for-profit and mores so than government hospitals, both in offering profitable and avoiding unprofitable services. They are also less likely than government hospitals to offer unprofitable, undersupplied services.

The results shed some light on the content of the nonprofit objective function as well. While profit-making must be in the objective function of all hospitals, it is likely lower on the list for nonprofits than for-profits. Controlling parties - be they managers, directors, doctors, or consumers - are making different choices that vary systematically by ownership. Further, the evidence presented here challenges the capture models, at least in their extreme forms, of nonprofit organizations (see, e.g., Pauly and Redisch, 1973). If doctors or other powerful nonprofit hospital employees were effectively maximizing their incomes, nonprofit hospitals would not offer unprofitable services. Perhaps hospital directors or regulations constrain employee capture, but the evidence presented here is consistent with a story of employee altruism. 
Interestingly, despite notoriously weak enforcement mechanisms, the results are consistent with law which requires nonprofits to act in the public interest (for detail on nonprofit law see Horwitz, 2003). More concretely, nonprofits are not required to offer unprofitable services but they choose to do so. Aside from the few jurisdictions in which attorneys general had and used their power to control hospital behavior during the study period, nonprofit and forprofit hospitals had the same opportunities to open and close units, and they faced the same public relations problems in doing so.

The results raise two further puzzles that need more attention. First, why do for-profits offer any unprofitable services? Businesses trying to maximize profits should not offer unprofitable product lines. For-profit hospitals, unlike other businesses however, maximize profits subject to a series of constraints having to do with the goods they provide. In addition, there are important, perhaps life-saving complementarities among health services. Institutions that provide surgical services, for example, need expensive and, often unprofitable, emergency support systems. In fact, opponents of single service specialty hospitals, such as freestanding cardiac centers, argue that specialty hospitals with limited emergency facilities jeopardize patient safety (Devers, Brewster and Ginsburg, 2003). Also, offering some unprofitable services such as obstetrical care is necessary to signal to doctors, patients, and insurers that the hospital is a fullservice institution. Finally, some services are loss-leaders. Unprofitable obstetric care, for example, attracts female patients who bring their families' profitable business to the hospital.

Second, why don't nonprofit hospitals offer all the profitable services as well as some unprofitable services? After all, nonprofits must value profits to some degree, even if less than for-profit hospitals, and they could use the proceeds to cross-subsidize. There are several plausible answers. For example, nonprofit hospitals may stick to core services like obstetrics and 
emergency care. The evidence here is mixed, showing that although nonprofits are less likely than for-profits to have a women's center or home health care, they are also more likely to have peripheral services like fitness centers.

Another plausible answer, following Newhouse's model, is that nonprofits differentially value quality. The evidence presented here is consistent with the quality explanation. It is unlikely that the most profitable mix of services is the most medically appropriate mix. Public payment rates are set through a complex and changing process based on, among other factors, the evolving judgment or reacting to past errors of rate-setters, imperfect adjustments for demographic and geographic characteristics of hospital markets, and the political strength of interested parties. Private payment rates also result from complex negotiations and relative bargaining power. This messy process does not inspire faith that regulators have found the right price in terms of medical quality. For these reasons, the rapid and large responses to changes in post-acute care profitability raise doubts that those changes were initiated for quality reasons. We need more study on how and, indeed, whether these processes produce incentives for hospitals to provide a medically appropriate service mix.

The preliminary results also suggest that hospital behavior depends on the ownership of its neighbors. Nonprofits and for-profits are both more likely to offer a profitable service and less likely to offer an unprofitable service in for-profit markets than in other markets. Government hospitals, however, appear to be relatively robust to outside influence; while they were more likely to offer a profitable service in for-profit markets than other markets, the results did not extend to unprofitable or variable profit services. The sensitivity tests related to geography, particularly the HRR fixed effects tests, suggest that there is a neighboring hospital effect rather than a market demand effect. And, given the breadth of services tested, an 
alternative theory based on market demand heterogeneity would require the unlikely scenario that an entering hospital could to gather information on and make choices about complex bundles of good. With only these results, however, it is difficult to differentiate between causal explanations such as isomorphism, local culture, competition, or market segmentation.

These results have practical implications for tax policy and health care regulatory policy which are worth noting, though are discussed in detail elsewhere (Horwitz, 2003). First, theory supports subsidizing nonprofit organizations on efficiency grounds based on the positive externalities they create (e.g. medical research, education, and disease control) or the agency problems they solve (e.g. they are more trustworthy decision-makers), which could be tested in many ways (Gentry and Penrod, 2000). These findings suggest that in measuring community benefit, policymakers should consider more than the provision of uncompensated care.

For example, in addition to public goods such as relatively unprofitable care for the poor, nonprofits provide private goods such as the availability of medically appropriate services for insured patients. To the extent that well-insured or wealthy patients want unprofitable services, they may not be able to buy them because of distortions caused by regulations forcing hospitals to take all comers. Well-insured patients, for example, may want and be willing to pay for a local trauma center. Under normal market conditions, a for-profit hospital would meet this demand. But, because hospitals must stabilize nonpaying, emergency patients before transferring them to other hospitals, trauma centers can become big money losers. Nonprofits and government hospitals can address this allocative inefficiency because they decide which services to provide on grounds other than profit maximization.

Finally, ownership might be used helpfully to regulate. When purchasing goods such as healthcare, where payers cannot specify the goods they want to buy nor monitor their supply, 
payment incentives should be low-powered to avoid under-serving needy patients (Newhouse, 2001). Complicated reimbursement systems have been developed to combat the risks of contracting under these circumstances, namely selection and skimping. With evidence that the responsiveness to financial incentives differ by form, payers could adjust rates by or selectively contract with different firm types. 


\section{References}

"Hospitals Continue Move into Home Care: Coming Changes in Reimbursement Expected to Promote Development of Programs Offering Continuum of Care," Modern Healthcare. 1993, 28.

"Jackhammer Could Crush Cost of Treating Kidney Stones," Modern Healthcare. 1991, 19.

Altman, Stuart H. and Henderson, Mary G. "Introduction," S. H. Altman, C. Brecher, M. G. Henderson and K. E. Thorpe, Competition and Compassion. Ann Arbor, Michigan: Health Administration Press, 1989,

Anonymous Interviewee. "Ge Medical Systems Sales Representative," Telephone Interview, Needham, Massachusetts, 2002.

Barro, Jason R. "Hospital Conversions to for-Profit Status: Causes and Consequences." 1998, pp. 38.

Becker, Cinda. "Imaging: The Next Generation," Modern Healthcare. 2000, 48.

Ben-Ner, Avner. "Nonprofit Organizations: Why Do They Exist in Market Economies?," New Haven: Yale Program on Non-Profit Organizations, 1983.

Ben-Ner, Avner and Gui, Benedetto. The Nonprofit Sector in the Mixed Economy. Ann Arbor, Michigan: University of Michigan Press, 1993.

Blecher, Michele Bitoun. "Capital: Who's Got It? How to Get It!," Hospitals \& Health Networks. 1997.

BNA Health Care Daily. "Medicaid: Louisiana Gov. Edwards Proposes 12 Percent Cut in Program Spending," 1995.

Brennan, Troyen. "Telephone Interview with President, Brigham and Women's Hospital Physician Organization," Boston, Massachusetts, 2002.

Commission, Medicare Payment Advisory. "Report to Congress: Medicare Payment Policy, Section 3a," Washington: Medicare Payment Advisory Commission, 2004, 69-101.

Cromwell, Jerry; Dayhoff, Debra and Thoumaian, Armen H. "Cost Savings and Physician Responses to Global Bundled Payments for Medicare Heart Bypass Surgery." Health Care Financing Review, 1997, 19(1), pp. 41-57.

Cutler, David and Huckman, Robert S. "Technological Development and Medical Productivity: The Diffusion of Angioplasty in New York State." Journal of Health Economics, 2003, 22, pp. 187-217. 
Cutler, David M. and Horwitz, Jill R. "Converting Hospitals from Not-for-Profit to for-Profit Status: Why and What Effects?," D. M. Cutler, The Changing Hospital Industry: Comparing Not-for-Profit and for-Profit Institutions. Chicago: University of Chicago Press, 2000, 45-79.

Cutler, David M.; McClellan, Mark and Newhouse, Joseph P. "How Does Managed Care Do It?" RAND Journal of Economics, 2000, 31(3), pp. 526-48.

Cutler, David M.; McClellan, Mark; Newhouse, Joseph P. and Remler, Dahlia. "Pricing Heart Attack Treatments," D. M. Cutler and E. R. Berndt, Medical Care Output and Productivity. Chicago and London: The University of Chicago Press, 2001, 305-62.

Dang, Shirley. "Ground Broken for Heart Hospital," Milawaukee Journal Sentinel. Milwaukee, Wisconsin, 2002, $1 \mathrm{~d}$.

Danzon, Patricia M. "Hospital "Profits": The Effects of Reimbursement Policies." Journal of Health Economics, 1982, 1(1), pp. 29-52.

Deangelis, Peter. "Hospital Based Snfs an Alternative to Empty Beds." Health Care Financial Mangement, 1987, 41(8), pp. 60-68.

Deloitte \& Touche. "U.S. Hospitals and the Future of Health Care," Boston, Massachusetts: Deloitte \& Touche, 1990.

Devers, Kelly J.; Brewster, Linda R. and Ginsburg, Paul B. "Specialty Hospitals: Focused Factories or Cream Skimmers?," Washington, D.C.: Center for Studying Health System Change, 2003.

Dhossche, Dirk M. and Ghani, Shareh O. "A Study of Recidivism in the Psychiatric Emergency Room." Annals of Clinical Psychiatry, 1998, 10(2), pp. 59-67.

Duggan, Mark G. "Hospital Ownership and Public Medical Spending." Quarterly Journal of Economics, 2000, 115(4), pp. 1343-73.

Eisenberg, Jeffrey S. "Ers on Critical List," Focus. 1990.

Ellison, James M.; Blum, Nancy and Barksy, Arthur. "Repeat Visitors in the Psychiatric Emergency Service: A Critical Review of the Data." Hospital \& Community Psychiatry, 1986, 37(1), pp. 37-41.

Fowler, Frances J. "Subacute Care Offers Flexibility, Revenue," Modern Healthcare. 1992, 50.

Frank, Richard and Salkever, David. "Market Forces, Diversification of Activity, and the Mission of Not-for-Profit Hospitals," D. M. Cutler, The Changing Hospital Industry: Comparing Not-for-Profit and for-Profit Institutions. Chicago, Illinois: University of Chicago Press, 2000, 195-215. 
. "Nonprofit Organization in the Health Sector." The Journal of Economic Perspectives, 1994, 8(4), pp. 129-44.

Gallagher, Mike. "Bitter Medicine: Presbyterian Plans Painful for Doctor," Albuquerque Journal. Albuquerque, New Mexico, 1998.

Gaynor, Martin and Haas-Wilson, Deborah. "Change, Consolidation, and Competition, in Health Care Markets." Journal of Economic Perspectives, 1999, 13(1), pp. 141-64.

Gentry, William M. "Debt, Investment, and Endowment Accumulation: The Case of Not-forProfit Hospitals." Journal of Health Economics, 2002, 21(5), pp. 845-72.

Gentry, William M. and Penrod, John R. "The Tax Benefits of Not-for-Profit Hospitals," D. M. Cutler, The Changing Hospital Industry: Comparing Not-for-Profit and for-Profit Institutions. Chicago, Illinois: University of Chicago Press, 2000, 285-324.

Geriatric Health Ventures Incorporated. "Subacute Skilled Nursing," Modern Healthcare. 1992, 29.

Ginsburg, Paul B. "Are Focused Factories the Wave of the Future?" Frontiers of Health Services Management, 2000, 16(3), pp. 41-46.

Glaeser, Edward L. and Shleifer, Andrei. "Not-for-Profit Entrepreneurs." Journal Of Public Economics, 2001, 81(1), pp. 99-115.

Gottlieb, Gary. "Telephone Interview, President, Brigham and Women's Hospital," Telephone Interview, February 14, 2002. Boston, Massachusetts, 2002.

Gresenz, C.R.; Rogowski, J. and Escarce, J.J. "Updated Variable-Radius Measures of Hospital Competition." Health Services Research, 2004, 39(2), pp. 417-30.

Grossman, Jerome H. "An Economic History of Healthcare in Massachusetts: 1990-2000," Cambridge, Massachusetts: Center for Business and Government, Kennedy School of Government, Harvard University, 2000.

_. "Telephone Interview, Chairman Emeritus, New England Medical Center," Telephone Interview, June 14, 2002. Cambridge, Massachusetts, 2002.

Hansmann, Henry. "The Role of Nonprofit Enterprise." Yale Law Journal, 1980, 89, pp. 835901.

Heffler, Stephen ; Smith, Sheila; Keehan, Sean; Clemens, M. Kent; Zezza, Mark and Truffer, Christopher. "Health Spending Projections through 2013." Health Affairs, 2004, (Web Exclusive), pp. w4,79-w4,93.

Helbing, Charles and Cornelius, Elizabeth S. "Snfs." Health Care Financing Review, 1992, 14(Supplement), pp. 97-123. 
Helbing, Charles; Sangl, Judith A. and Silverman, Herbert A. "Home Health Agency Benefits." Health Care Financing Review, 1992, Annual Supplement, pp. 125-48.

Hirth, Richard A. "Consumer Information and Competition between Nonprofit and for-Profit Nursing Homes." Journal of Health Economics, 1999, 18, pp. 219-40.

Horwitz, Jill R. "Research Note: Relative Profitability of Acute Care Hospital Services," Health Affairs Online Supplement, content.healthaffairs.org/cgi/content/full/24/3/790/DC1, 2005.

. "Why We Need the Independent Sector: The Behavior, Law, and Ethics of Non-for-Profit Hospitals." UCLA Law Review, 2003, 50(6), pp. 1345-411.

James, Estelle and Rose-Ackerman, Susan. The Nonprofit Enterprise in the Market Economics. Chur, Switzerland: Harwood Academic Publishers, 1986.

Lakdwawalla, Darius and Philipson, Tomas. "The Nonprofit Sector and Industry Performance." 1999.

Liu, Korbin; Gage, Barbara; Harvell, Jennie; Stevenson, David and Brennan, Niall. "Medicare's Post-Acute Benefit: Background, Trends, and Issues to Be Faced," The Urban Institute, 1999.

Lutz, Sandy. "Home Care Pps Holds Promise of Profits," Modern Healthcare. 1992, 44.

Malani, Anup and Choi, Albert. "Are Non-Profit Firms Simply for-Profits in Disguise? Evidence from the Executive Compensation in the Nursing Home Industry." The University of Virginia John M. Olin Program in Law and Economics Working Paper Series, 2004.

Manning, David L. "Investing in the Twenty-First Century Hospital." Health Affairs, 1997, 16(2), pp. 108-11.

McClellan, Mark and Staiger, Douglas. "Comparing Hospital Quality at for-Profit and Not-forProfit Hospitals," D. M. Cutler, The Changing Hospital Industry: Comparing Not-for-Profit and for-Profit Institutions. Chicago, Illinois: University of Chicago Press, 2000, 93-112.

Melnick, Glenn; Serrato, Carl and Mann, Joyce. "Prospective Payments to Hospitals: Should Emergency Admissions Have Higher Rates?" Health Care Financing Review, 1989, 10(3), pp. 29-39.

Meyer, Harris. "Focused Factories: Are You Ready for the Competition?," Hospitals \& Health Networks. 1998.

Newhouse, Joseph P. "Interview with John D. Macarthur Professor of Health Policy and Management and Director of the Division of Health Policy Research and Education Harvard University," Interview, April 2, 2002. Boston, Massachusetts, 2002a.

. "Medicare," J. A. Frankel and P. R. Orszag, American Economic Policy in the 1990s. Cambridge, Massachusetts: MIT Press, 2002b, 899-955. 
2001.

. "Medicare Policy in the 1990s," Cambridge: National Bureau of Economic Research,

. "Toward a Theory of Nonprofit Instiutions: An Economic Model of a Hospital." The American Economic Review, 1970, 60(1), pp. 64-74.

Norton, E.C. and Staiger, Doug. "How Hospital Ownership Affects Access to Care for the Uninsured." RAND Journal of Economics, 1994, 25, pp. 171-85.

O'Donnell, Kevin. "Home Care Shaping up as Competitive Necessity," Modern Healthcare. $1993,34$.

Pauly, Mark V. and Redisch, Michael. "The Not-for-Profit Hospital as Physicians' Cooperative." American Economic Review, 1973, 63(March), pp. 87-99.

Picone, Gabriel A.; Chou, Shin-Yi and Sloan, Frank. "Are for-Profit Hospital Conversions Harmful to Patients and to Medicare?" RAND J. of Econ., 2002, 33(3), pp. 507-23.

Romano, Michael. "The Week in Healthcare," Modern Healthcare. 2004, 10.

Roomkin, Myron J. and Weisbrod, Burton A. "Managerial Compensation and Incentives in forProfit and Nonprofit Hospitals." Journal of Law, Economics, and Organization, 1999, 15(3), pp. 750-81.

Rose-Ackerman, Susan. "Altruism, Not-for-Profits, and Economic Theory." Journal of Economic Literature, 1996, 34, pp. 701-28.

Rosenbaum, Paul R. and Rubin, Donald B. "The Central Role of the Propensity Score in Observational Studies for Causal Effects." Biometrika, 1983, 70(1), pp. 41-55.

. "Reducing Bias in Observational Studies Using Subclassification on the Propensity Score." Journal of the American Statistical Association, 1984, 79(387), pp. 516-24.

Salamon, Lester M. "Partners in Public Service: The Scope and Theory of Government Nonprofit Relations," W. W. Powell, The Nonprofit Sector. New Haven, Connecticut: Yale University Press, 1987, 99-117.

Scharmach, Nancy J. "Diversifying into Skilled Nursing Care: It Can Fill Beds, Manage Medicare Costs, and Meet a Need," Modern Healthcare. 1990, 30.

Showalter, J. Stuart. Southwick's the Law of Healthcare Administration. Chicago, Illinois: Health Administration Press, 1999.

Shwed, H. "Teaching Emergency Room Psychiatry." Hospital \& Community Psychiatry, 1980, 31(8), pp. 558-62. 
Silverman, Elaine and Skinner, Jonathan. "Are for-Profit Hospitals Really Different? Medicare Upcoding and Market Structure," Cambridge, Massachusetts: National Bureau of Economic Research, 2000.

Sloan, Frank. "Not-for-Profit Ownership and Hospital Behavior," A. J. Culyer and J. P. Newhouse, Handbook of Health Economics. Elsevier Science B.V., 2000, 1141-74.

Sloan, Frank A. ; Picone, Gabriel A.; Taylor Jr., Donald H. and Chou, Shin-Yi. "Hospital Ownership and Cost and Quality of Care: Is There a Dime's Worth of Difference?" Journal of Health Economics, 2001, 20(1), pp. 1-21.

Snail, T.S. and Robinson, J.C. "Organizational Diversification in the American Hospital." Annual Review of Public Health, 1998, 19, pp. 417-53.

Stout, Heidi. "A Healthy Bottom Line," The Business Journal. Portland, 2001.

Tye, Larry. "Beth Israel to Keep Psychiatric Unit Most Beds to Stay," Boston Globe. Boston, Massachusetts, 2001, B2.

Vladeck, Bruce C. and Miller, Nancy A. "The Medicare Home Health Initiative." Health Care Financing Review, 1994, 16(1), pp. 7-16.

Wagner, Lynn. "Hospitals Seeing Benefit in Offering Long-Term Care," Modern Health Care. 1989, 40-42.

Wagner, Mary. "Cardiac Administration Taking Off at Hospitals," Modern Healthcare. 1991, 28.

Wedig, Gerard J.; Hassan, Mahmud and Morrisey, Michael A. "Tax-Exempt Debt and the Capital Structure of Nonprofit Organizations: An Application to Hospitals." The Journal of Finance, 1996, 51(4), pp. 1247-83.

Wedig, Gerard J.; Hassan, Mahmud and Sloan, Frank. "Hospital Investment Decisions and the Cost of Capital." Journal of Business, 1989, 62(4), pp. 517-37.

Weisbrod, Burton A. The Nonprofit Economy. Cambridge, Massachusetts: Harvard University Press, 1988.

Wennberg, John E. "Understanding Geographic Variations in Health Care Delivery." New England Journal of Medicine, 1999, 340(1), pp. 52-53.

Winslow, Ron. "Coronary Bypass: Fed-up Cardiologists Invest in Own Hospital Just for Heart Disease -- They'll Regain Autonomy, but Critics See a Grab for Most-Profitable Care -- a Showdown in Albuquerque," Wall Street Journal. New York, New York, 1999, A1. 
Woodward, Albert; Epstein, Joan; Gfroerer, Joseph; Melnick, Daniel; Thoreson, Richard and Wilson, Douglas. "The Drug Abuse Treatment Gap: Recent Estimates." Health Care Financing Review, 1997, 18(3), pp. 5-17.

Young, Dennis R. "Entrepreneurship and the Behavior of Nonprofit Organizations: Elements of a Theory," M. J. White, Nonprofit Firms in a Three Sector Economy. Washington, D.C.: Urban Institute, 1981. 
Table 1. Comparison of Services Offered at Study Hospitals, by Ownership, 1988-2000

\begin{tabular}{|c|c|c|c|c|c|}
\hline Service & Percent & $\begin{array}{l}\text { Relatively } \\
\text { Profitable }\end{array}$ & $\begin{array}{c}\text { Relatively } \\
\text { Unprofitable } \\
\end{array}$ & Variable & $\begin{array}{l}\text { Capital } \\
\text { Intensive }\end{array}$ \\
\hline AIDS (Outpatient) & 11 & & $\mathrm{X}$ & & \\
\hline AIDS Services & 54 & & $\mathrm{X}$ & & \\
\hline AIDS Unit & 04 & & $\mathrm{X}$ & & \\
\hline Alcohol Beds & 30 & & $\mathrm{X}$ & & \\
\hline Alcohol/ Drug (Outpatient) & 33 & & $\mathrm{X}$ & & \\
\hline Angioplasty & 40 & $\mathrm{X}$ & & & $\mathrm{X}$ \\
\hline Birthing Room & 69 & $\mathrm{X}$ & & & $\mathrm{X}$ \\
\hline Burn Treatment & 05 & & $\mathrm{X}$ & & $\mathrm{X}$ \\
\hline Cardiac Catheterization Lab & 54 & $\mathrm{X}$ & & & $\mathrm{X}$ \\
\hline Computed Tomography Scanner (CT Scanner) & 92 & $\mathrm{X}$ & & & $\mathrm{X}$ \\
\hline Child Psychiatric Services & 25 & & $\mathrm{X}$ & & \\
\hline Diagnostic Radioisotope Facility & 81 & $\mathrm{X}$ & & & \\
\hline Emergency Room & 96 & & $\mathrm{X}$ & & $\mathrm{X}$ \\
\hline Extracorporeal Shock-Wave Lithotripter & 17 & $\mathrm{X}$ & & & $\mathrm{X}$ \\
\hline Fitness Center & 24 & $\mathrm{X}$ & & & \\
\hline HIV Test & 60 & & $\mathrm{X}$ & & \\
\hline Home Health & 44 & & & $\mathrm{X}$ & \\
\hline Magnetic Resonance Imaging (MRI) & 46 & $\mathrm{X}$ & & & $\mathrm{X}$ \\
\hline Neonatal Intensive Care & 35 & $\mathrm{X}$ & & & $\mathrm{X}$ \\
\hline Obstetrics (beds) & 73 & & $\mathrm{X}$ & & \\
\hline Obstetrics (births) & 71 & & $\mathrm{X}$ & & \\
\hline Open Heart Surgery & 34 & $\mathrm{X}$ & & & $\mathrm{X}$ \\
\hline Orthopedic Surgery & 92 & $\mathrm{X}$ & & & \\
\hline Pediatric Intensive Care Unit & 22 & $\mathrm{X}$ & & & $\mathrm{X}$ \\
\hline Positron Emission Tomography & 06 & $\mathrm{X}$ & & & $\mathrm{X}$ \\
\hline Psychiatric (inpatient) & 49 & & $\mathrm{X}$ & & \\
\hline Psychiatric Emergency Services & 48 & & $\mathrm{X}$ & & \\
\hline Skilled Nursing & 35 & & & $\mathrm{X}$ & \\
\hline Single Photon Emission Computed Tomography & 45 & $\mathrm{X}$ & & & $\mathrm{X}$ \\
\hline Sports Medicine & 32 & $\mathrm{X}$ & & & \\
\hline Trauma Center & 25 & & $\mathrm{X}$ & & $\mathrm{X}$ \\
\hline Ultrasound & 96 & $\mathrm{X}$ & & & \\
\hline Women's Center & 47 & $\mathrm{X}$ & & & \\
\hline
\end{tabular}

SOURCE: Author's analysis of American Hospital Association Annual Surveys, 1988-2000.

NOTE: Includes all non-rural, general medical and surgical hospitals in MSAs $>1$ hospital. 
Table 2. Model Predictions

\begin{tabular}{|l|l|}
\hline Theory & Predictions \\
\hline $\begin{array}{l}\text { Objectives Theories: } \\
\text { Profit-seeking v. Community Need }\end{array}$ & $\begin{array}{l}\text { Profitable Services: } \mathrm{F}>\mathrm{N}>\mathrm{G} \\
\text { Unprofitable Services: } \mathrm{G}>\mathrm{N}>\mathrm{F}\end{array}$ \\
\hline $\begin{array}{l}\text { Capital Constraint Theories: } \\
\begin{array}{l}\text { Different capital sources explain different } \\
\text { investment decisions }\end{array}\end{array}$ & Services with high capital costs: F $>\mathrm{N}$ or $\mathrm{N}>\mathrm{F}$ \\
\hline $\begin{array}{l}\text { Market Theory: } \\
\text { Firms behave differently in different market }\end{array}$ & Unprofitable Services: $\begin{array}{l}\mathrm{N}_{\mathrm{F} \text { Markets }}<\mathrm{N}_{\text {Other Markets }} \\
\mathrm{G}_{\mathrm{F} \text { Markets }}<\mathrm{G}_{\text {Other Markets }}\end{array}$ \\
\hline
\end{tabular}

NOTE: $\mathrm{F}$ = for-profit; $\mathrm{N}=$ nonprofit; $\mathrm{G}=$ government.

Table 3. U.S. General Surgical and Medical Hospitals -Urban

\begin{tabular}{|r|r|r|r|r|}
\hline Year & Gov & NFP & FP & Total \\
\hline 1988 & 521 & 1863 & 530 & 2914 \\
\hline 1989 & 508 & 1843 & 518 & 2869 \\
\hline 1990 & 504 & 1830 & 494 & 2828 \\
\hline 1991 & 490 & 1829 & 478 & 2797 \\
\hline 1992 & 486 & 1803 & 470 & 2759 \\
\hline 1993 & 493 & 1783 & 469 & 2745 \\
\hline 1994 & 471 & 1760 & 467 & 2698 \\
\hline 1995 & 459 & 1713 & 483 & 2655 \\
\hline 1996 & 449 & 1680 & 487 & 2616 \\
\hline 1997 & 422 & 1634 & 506 & 2562 \\
\hline 1998 & 407 & 1642 & 481 & 2530 \\
\hline 1999 & 431 & 1692 & 473 & 2596 \\
\hline 2000 & 410 & 1682 & 470 & 2562 \\
\hline & 6,051 & 22,754 & 6,326 & 35,131 \\
\hline
\end{tabular}

SOURCE: Author's analysis of AHA Survey, 1988-2000.

NOTE: All federal hospitals except veterans' hospitals are excluded. Nonprofit hospitals include secular and religious hospitals. For-profit hospitals include proprietary and corporate hospitals. 
Table 4. Summary of Independent Variables

\begin{tabular}{|c|c|}
\hline Variable & Mean \\
\hline Nonprofit & 0.65 \\
\hline Government & 0.17 \\
\hline For-Profit & 0.18 \\
\hline Admission Quartile $1($ mean total admissions $=1,950)$ & 0.25 \\
\hline Admission Quartile 2 (mean total admissions $=5,410)$ & 0.25 \\
\hline Admission Quartile 3 (mean total admissions $=9,930)$ & 0.25 \\
\hline Admission Quartile 4 (mean total admissions $=20,420$ ) & 0.25 \\
\hline MSA Size 1 (population $<100,000)$ & 0.02 \\
\hline MSA Size $2(100,000<$ population $<250,000)$ & 0.14 \\
\hline MSA Size $3(250,000<$ population $<500,000)$ & 0.16 \\
\hline MSA Size $4(500,000<$ population $<1,000,000)$ & 0.16 \\
\hline MSA Size $5(1,000,000<$ population $<2,500,000)$ & 0.27 \\
\hline MSA Size 6 (population $>2,500,000$ ) & 0.25 \\
\hline Teaching Hospital & 0.13 \\
\hline Northeast & 0.21 \\
\hline South & 0.35 \\
\hline Midwest & 0.23 \\
\hline West & 0.21 \\
\hline$\%$ male & 0.49 \\
\hline$\%$ white & 0.79 \\
\hline$\%$ black & 0.13 \\
\hline In (household income) & $* 10.35$ \\
\hline$\%$ baby & 0.01 \\
\hline$\%$ age 1 to17 & 0.24 \\
\hline$\%$ age 18 to 29 & 0.19 \\
\hline$\%$ age 30 to 39 & 0.17 \\
\hline$\%$ age 40 to 49 & 0.09 \\
\hline$\%$ age 50 to 64 & 0.13 \\
\hline$\% \geq$ age 65 & 0.12 \\
\hline$\% \geq$ age 80 & 0.03 \\
\hline Elementary education & 0.18 \\
\hline High school diploma & 0.22 \\
\hline Some college & 0.20 \\
\hline College degree & 0.15 \\
\hline * approximately $\$ 31,250$ & \\
\hline
\end{tabular}

SOURCE: Author's analysis of AHA Annual Survey, 1988-2000. 
Figure 1. Probability of Offering Open Heart Surgery

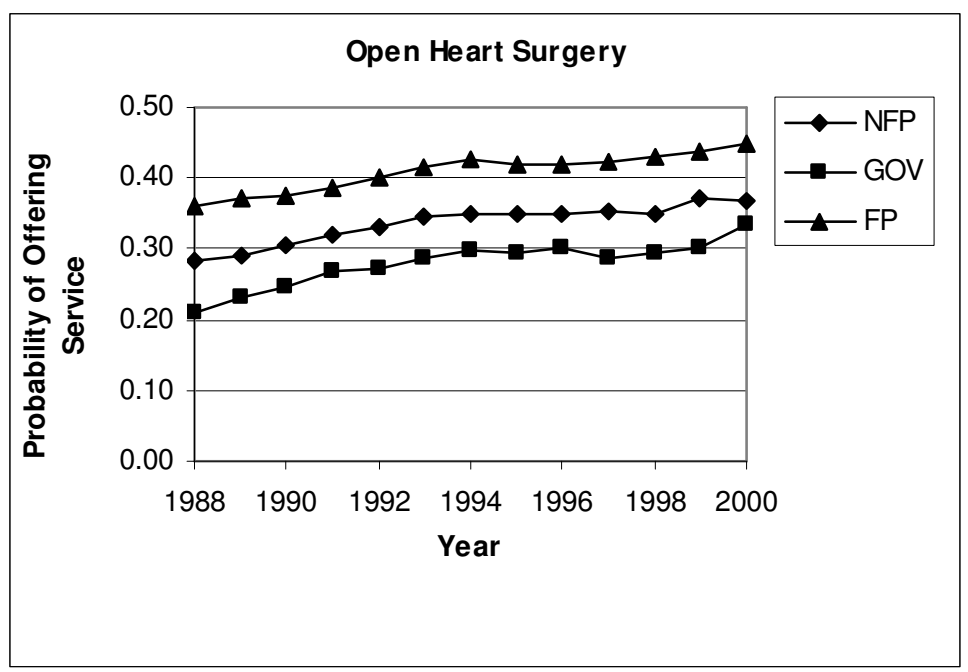

SOURCE: Author's analysis of data from American Hospital Association Annual Surveys, 1988-2000.

NOTES: Probit predicted probabilities include all general and surgical, non-rural hospitals in MSAs $>1$ hospital. P values are based on the chi-square test of the differences between average predicted probabilities of offering services $1988-2000$ by hospital type. (NFP v. FP: P<0.001; NFP v. Gov: P=0.001; FP v. Gov: P<0.001).

Figure 2. Probability of Offering Psychiatric Emergency

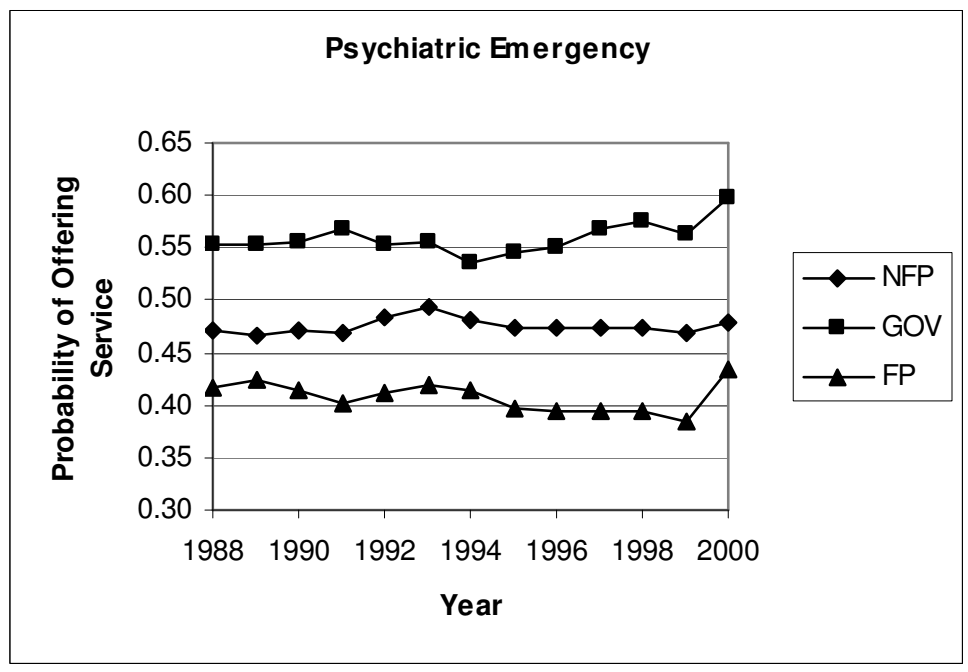

SOURCE: Author's analysis of data from American Hospital Association Annual Surveys, 1988-2000.

NOTES: Probit predicted probabilities include all general and surgical, non-rural hospitals in MSAs $>1$ hospital. P values are based on the chi-square test of the differences between average predicted probabilities of offering services 1988 - 2000 by hospital type. (NFP v. FP: P=0.001; NFP v. Gov: P<0.001; FP v. Gov: P<0.001). 
Figure 3. Probability of Offering Home Health Service

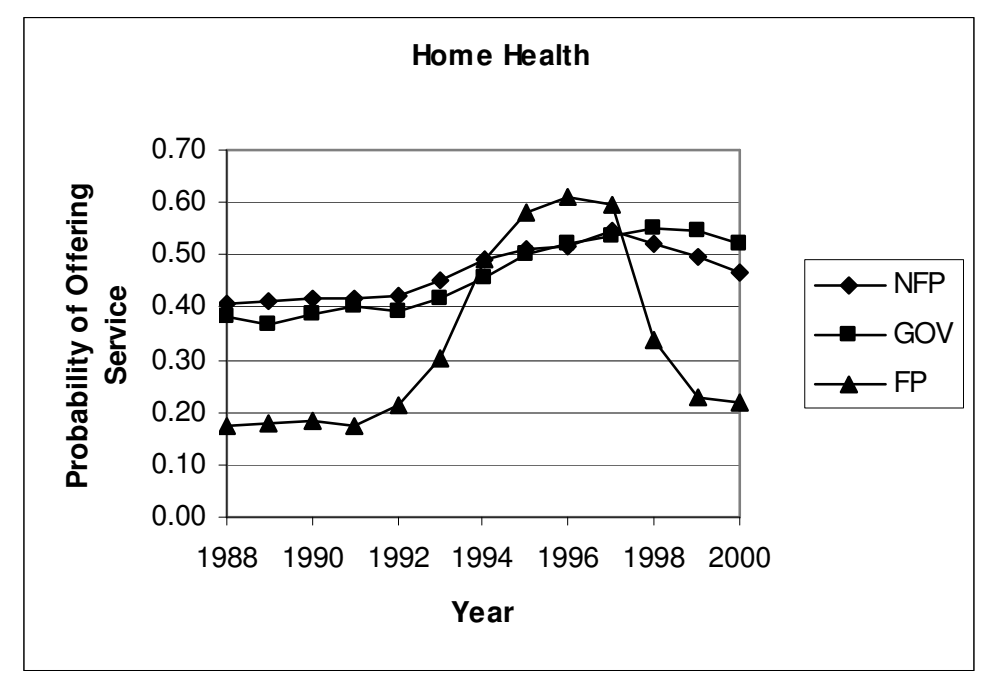

SOURCE: Author's analysis of data from American Hospital Association Annual Surveys, 1988-2000.

NOTES: Probit predicted probabilities include all general and surgical, non-rural hospitals in MSAs $>1$ hospital. P values are based on the chi-square test of the differences between average predicted probabilities of offering services 1988 - 2000 by hospital type. (NFP v. FP: P<0.001; NFP v. Gov: P=0.0705; FP v. Gov: P<0.001). 
Figure 4. Probability of Offering Extra Corporeal Shockwave Lithotripter

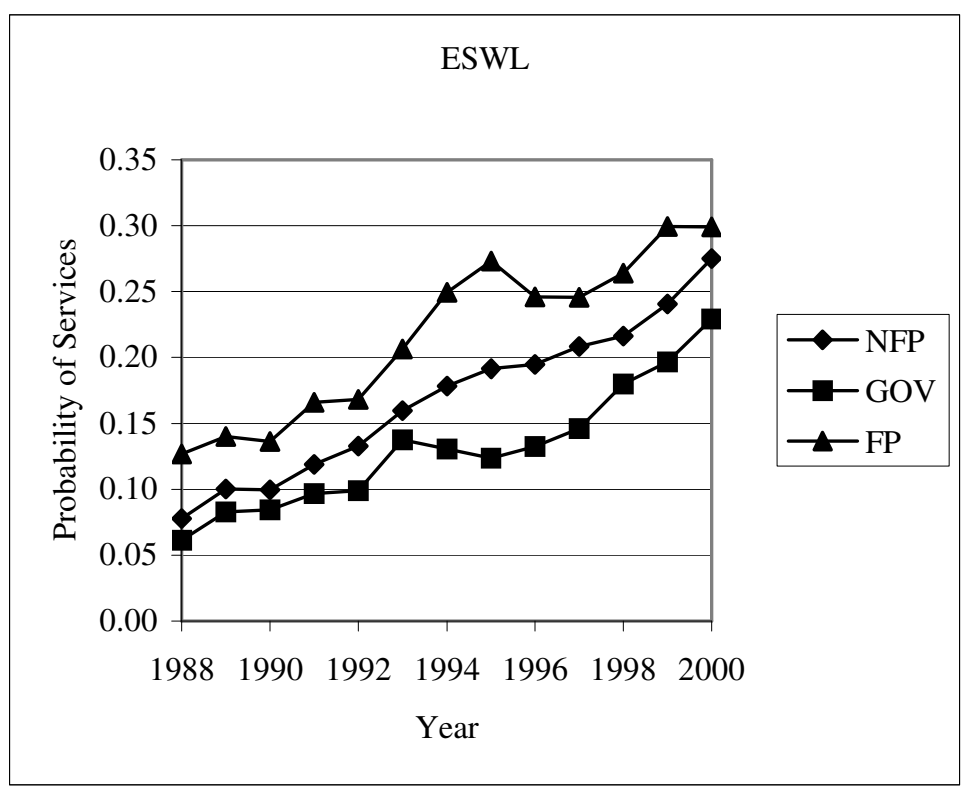

SOURCE: Author's analysis of data from American Hospital Association Annual Surveys, 1988-2000.

NOTES: Probit predicted probabilities include all general and surgical, non-rural hospitals in MSAs $>1$ hospital. P values are based on the chi-square test of the differences between average predicted probabilities of offering services $1988-2000$ by hospital type. (NFP v. FP: P<0.001; NFP v. Gov: P=0.003; FP v. Gov: P<0.001).

Figure 5. Probability of offering MRI

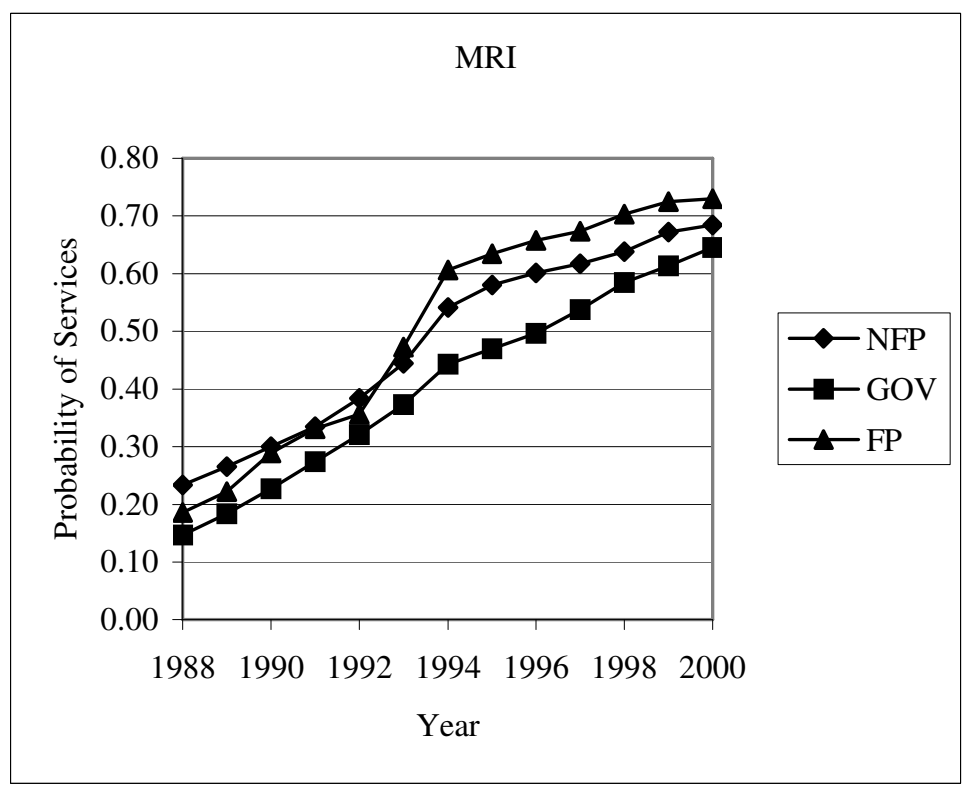

SOURCE: Author's analysis of data from American Hospital Association Annual Surveys, 1988-2000.

NOTES: Probit predicted probabilities include all general and surgical, non-rural hospitals in MSAs $>1$ hospital. P values are based on the chi-square test of the differences between average predicted probabilities of offering services 1988 - 2000 by hospital type. (NFP v. FP: P=0.191; NFP v. Gov: P<0.001; FP v. Gov: P<0.001). 
Table 5. Comparison of Services Offered by Ownership Type, 1988-2000

\begin{tabular}{|c|c|c|c|}
\hline Profitable Services & $\mathbf{F}>\mathbf{N}$ & $\mathbf{F}>\mathbf{G}$ & $\mathbf{N}>\mathbf{G}$ \\
\hline Angioplasty (1989-2000) & $\mathrm{Y}^{* * *}$ & $\mathrm{Y}^{* * *}$ & $\mathrm{Y}^{* * *}$ \\
\hline Birthing Room@ & $\mathrm{N}^{*}$ & $\mathrm{~N}$ & $\mathrm{Y}$ \\
\hline Cardiac Catheterization Lab & $\mathrm{Y}^{* * * *}$ & $\mathrm{Y}^{* * *}$ & $\mathrm{Y}^{* * *}$ \\
\hline Computed Tomography Scanner (CT Scanner) & $\mathrm{N}$ & $\mathrm{Y}$ & $\mathrm{Y}^{*}$ \\
\hline Diagnostic Radioisotope Facility & $\mathrm{N}^{*}$ & $\mathrm{Y} * * *$ & $\mathrm{Y}^{* * *}$ \\
\hline Extracorporeal Shock-Wave Lithotripter & $\mathrm{Y} * * *$ & $\mathrm{Y} * * *$ & $\mathrm{Y}^{* * *}$ \\
\hline Fitness Center & $\mathrm{N}^{* *}$ & $\mathrm{~N}$ & $\mathrm{Y} * *$ \\
\hline Magnetic Resonance Imaging & Y & $\mathrm{Y}^{* * *}$ & $\mathrm{Y}^{* * *}$ \\
\hline Neonatal Intensive Care@ (beds $>0)$ & $\mathrm{Y} * * *$ & $\mathrm{Y} * * *$ & $\mathrm{~N}^{* * *}$ \\
\hline Open Heart Surgery & $\mathrm{Y} * * *$ & $\mathrm{Y} * * *$ & $\mathrm{Y} * * *$ \\
\hline Orthopedic Surgery (1989-1993) & $\mathrm{N}$ & $\mathrm{Y}^{* * *}$ & $\mathrm{Y}^{* * *}$ \\
\hline Pediatric Intensive Care@(beds $>1)$ & $\mathrm{Y} * * *$ & $\mathrm{Y}^{* * *}$ & $\mathrm{~N} * * *$ \\
\hline Positron Emission Tomography (1990-2000) & $\mathrm{Y}$ & $\mathrm{Y}^{*}$ & $\mathrm{Y}$ \\
\hline Single Photon Emission Computed Tomography (1990-2000) & $\mathrm{N}^{* *}$ & $\mathrm{Y}$ & $\mathrm{Y} * * *$ \\
\hline Sports Medicine & $=$ & $\mathrm{Y}^{* * *}$ & $\mathrm{Y}^{* * *}$ \\
\hline Ultrasound & $\mathrm{N}^{* * *}$ & $\mathrm{~N}$ & $\mathrm{Y}$ \\
\hline Women's Center@ & $\mathrm{Y}^{* * *}$ & $\mathrm{Y}^{* * *}$ & $\mathrm{Y}^{*}$ \\
\hline Unprofitable Services & $\mathbf{F}>\mathbf{N}$ & $\mathbf{F}>\mathbf{G}$ & $\mathbf{N}>\mathbf{G}$ \\
\hline AIDS (Outpatient) (1988-1993) & $\mathrm{N}$ & $\mathrm{N} * * *$ & $\mathrm{~N}^{* * *}$ \\
\hline AIDS Services (1994-2000) & $\mathrm{N}^{* * *}$ & $\mathrm{~N}^{* * *}$ & $\mathrm{~N}^{* * *}$ \\
\hline AIDS Unit (1988-1993) & $\mathrm{Y}^{* *}$ & $\mathrm{~N}$ & $\mathrm{~N} * * *$ \\
\hline Alcohol/Drug Inpatient (Beds >1) & $\mathrm{Y}^{* * *}$ & $\mathrm{Y}^{*}$ & $\mathrm{~N}^{* * * *}$ \\
\hline Alcohol/ Drug Outpatient & $\mathrm{N} * * *$ & $\mathrm{~N} * * *$ & $\mathrm{~N}^{* * *}$ \\
\hline Burn Treatment $($ Beds $>0)$ & $\mathrm{Y}$ & $\mathrm{N}^{*}$ & $\mathrm{~N} * * *$ \\
\hline Child/Adolescent Psychiatric @ (Beds > 0) & $\mathrm{N}$ & $\mathrm{N}^{*}$ & $\mathrm{~N}$ \\
\hline Emergency Room & $\mathrm{N}^{* *}$ & $\mathrm{Y}$ & $\mathrm{Y}^{* * *}$ \\
\hline EmergencyRoom@ & $\mathrm{N}^{*}$ & $=$ & $\mathrm{Y}$ \\
\hline HIV Test (1988-1991) & $\mathrm{N}$ & $\mathrm{N}^{*}$ & $\mathrm{~N}^{*}$ \\
\hline Obstetrics (beds >2) @ & $\mathrm{N}$ & $\mathrm{N}$ & $\mathrm{N}$ \\
\hline Obstetrics (births >=100) @ & $\mathrm{N}^{* * *}$ & $\mathrm{~N} * *$ & $\mathrm{~N}$ \\
\hline Psychiatric Inpatient $(1989-2000$, beds $>1)$ & $\mathrm{Y}^{* *}$ & $\mathrm{~N} * * *$ & $\mathrm{~N} * * *$ \\
\hline Psychiatric Emergency Services & $\mathrm{N}^{* * *}$ & $\mathrm{~N}^{* * *}$ & $\mathrm{~N} * * *$ \\
\hline Psychiatric Emergency Services@ & $\mathrm{N}^{* * *}$ & $\mathrm{~N}^{* * *}$ & $\mathrm{~N}$ \\
\hline Trauma Center & $\mathrm{N}^{* *}$ & $\mathrm{~N}$ & $\mathrm{Y}$ \\
\hline TraumaCenter@ & $\mathrm{N}^{* *}$ & $\mathrm{~N} * * *$ & $\mathrm{~N} * * *$ \\
\hline
\end{tabular}


Table 6. Comparison of Probability of Offering Services With Variable Profits, by Ownership Type

\begin{tabular}{|c|c|c|c|c|c|c|}
\hline & \multicolumn{3}{|c|}{ Profitable (1992-1996) } & \multicolumn{3}{|c|}{ Unprofitable (1997-2000) } \\
\hline & $\mathbf{F}$ & $\mathbf{N}$ & G & $\mathbf{F}$ & $\mathbf{N}$ & G \\
\hline Home Health & +39.3 & +9.7 & +12.7 & -37.6 & -7.7 & -1.5 \\
\hline Skilled Nursing & +28.1 & +15.4 & +4.9 & +2.8 & +4.7 & +9.7 \\
\hline
\end{tabular}

SOURCE: Author's analysis of data American Hospital Association Annual Surveys 1988-2000.

NOTES: $\mathrm{F}$ = For-profit; $\mathrm{N}=$ Not-for-Profit, $\mathrm{G}=$ Government. Values are the percentage point change in probability of offering service during the years indicated. 


\section{Table 7. Hypothesis Tests}

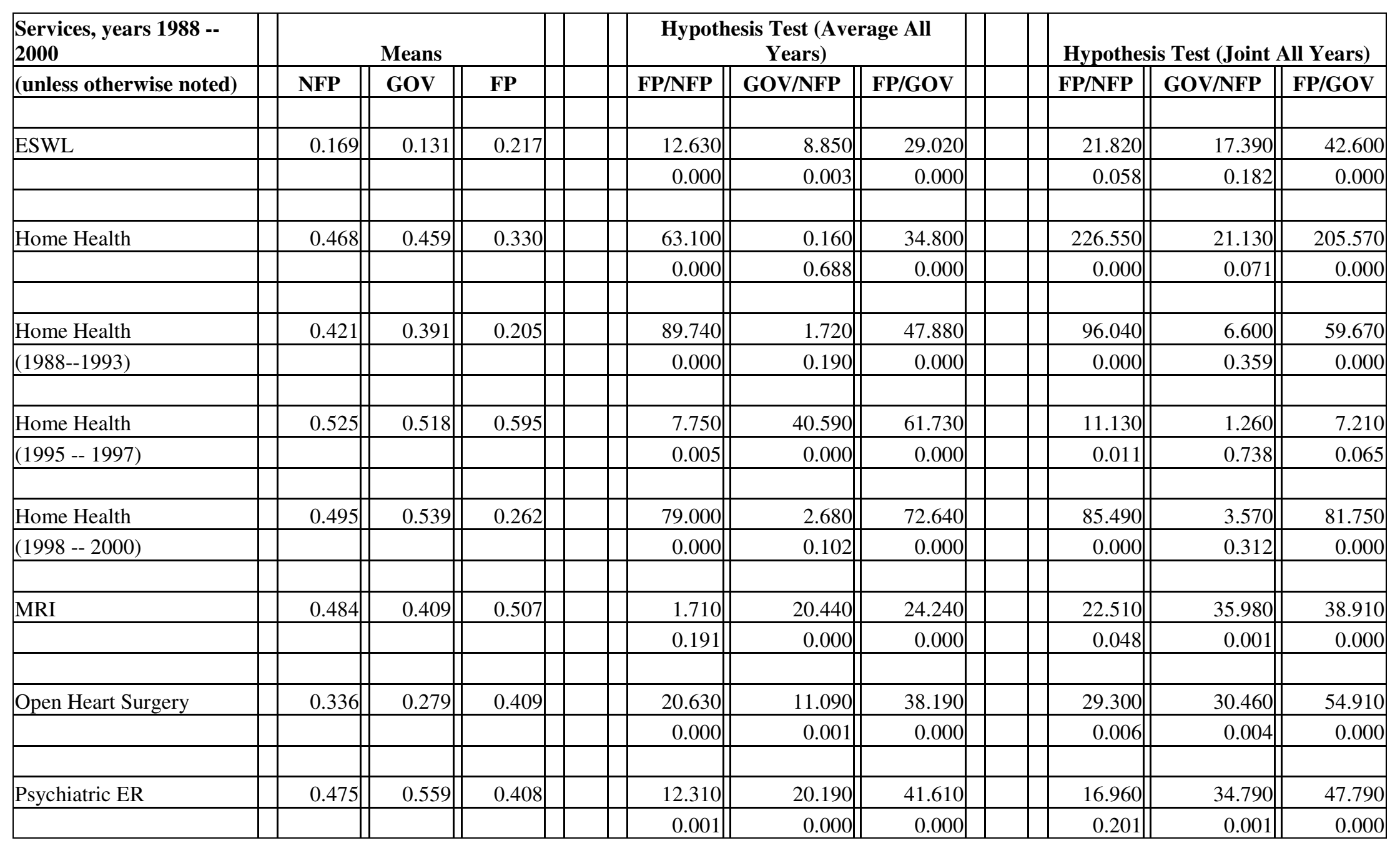


Figure 6. Open Heart Surgery, Market Penetration

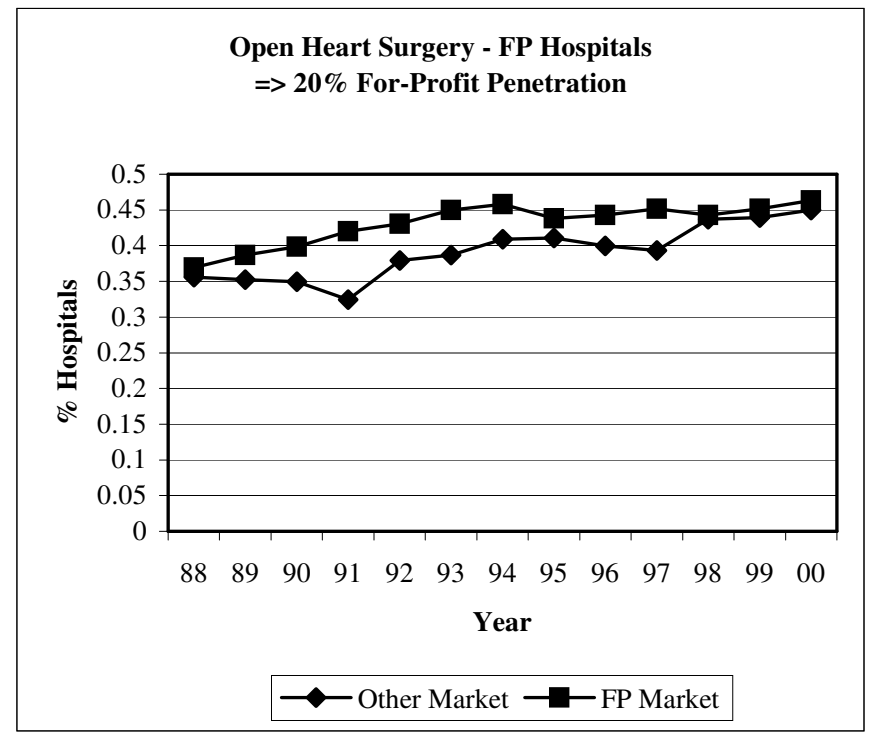

NOTES: Probit predicted probabilities include all general and surgical, non-rural hospitals in MSAs $>1$ hospital. $\mathrm{P}$ values are based on the chi-square test of the differences between average predicted probabilities of offering services $1988-2000$ by hospital type. (FP v other: not significant).

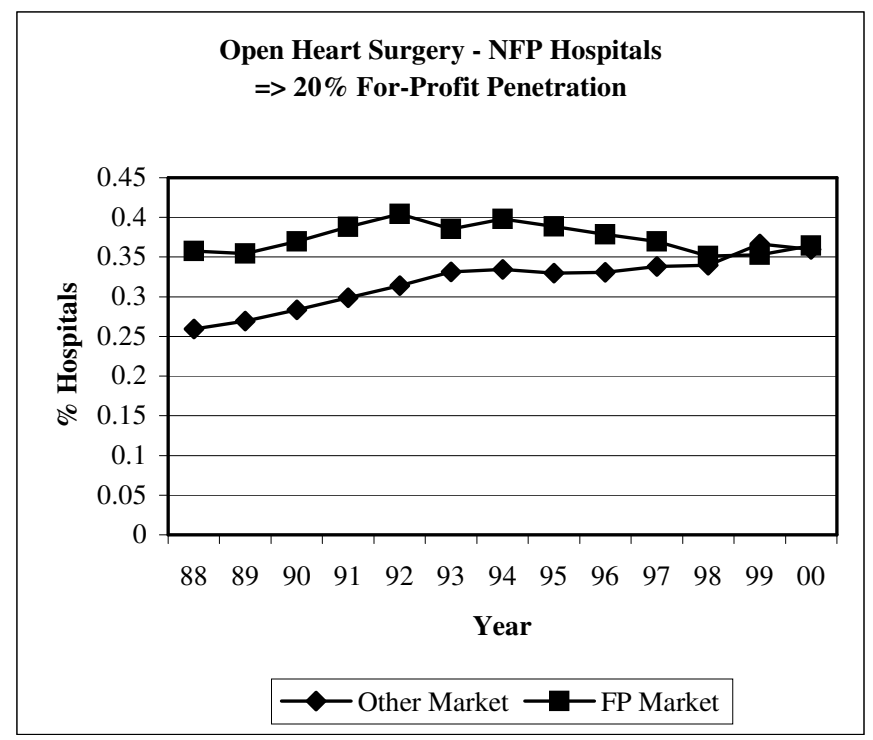

NOTES: Probit predicted probabilities include all beneral and surgical, non-rural hospitals in MSAs $>1$ hospital. $\mathrm{P}$ values are based on the chi-square test of the differences between average predicted probabilities of offering services $1988-2000$ by hospital type. (FP v other: $\mathrm{P}<0.05$ ).

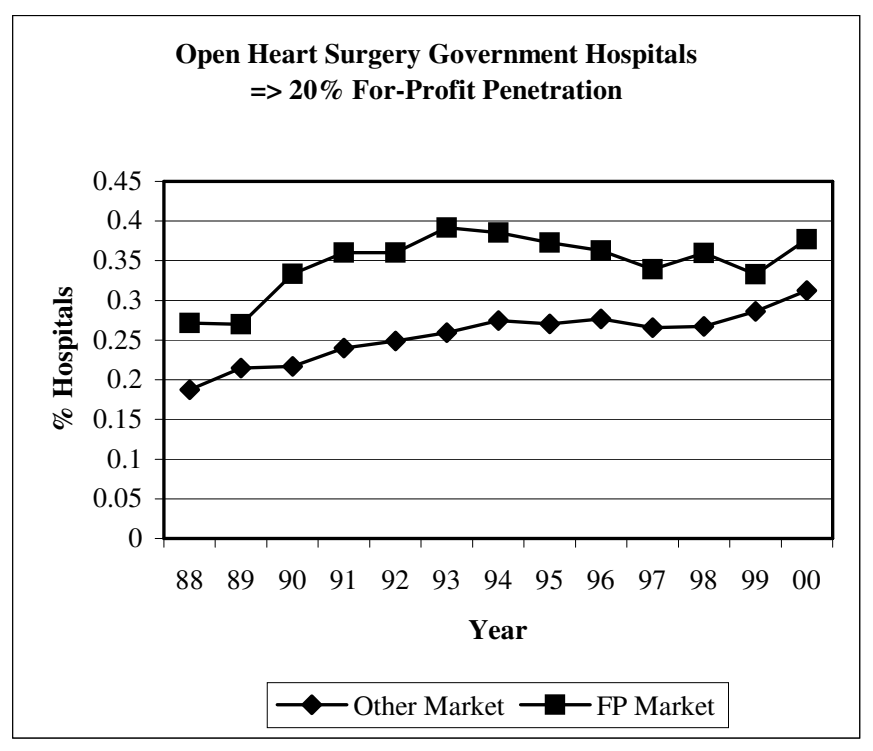

NOTES: Probit predicted probabilities include all general and surgical, non-rural hospitals in MSAs $>1$ hospital. $\mathrm{P}$ values are based on the chi-square test of the differences between average predicted probabilities of offering services 1988 - 2000 by hospital type. (FP v other: $\mathrm{P}<0.01$ ). 
Figure 7. Home Health, Market Penetration

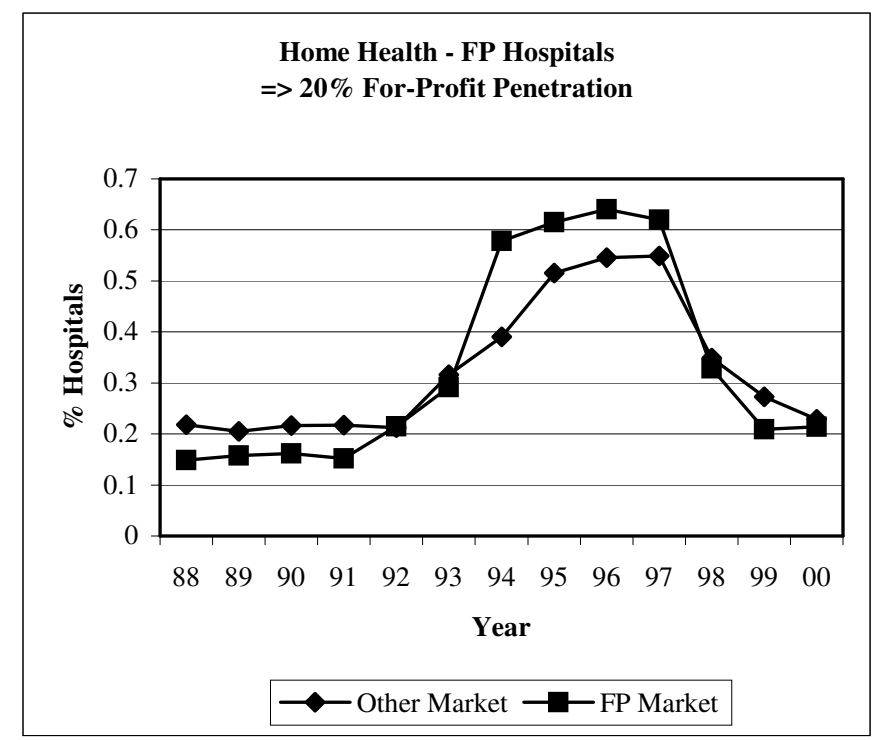

NOTES: Probit predicted probabilities include all general and surgical, non-rural hospitals in MSAs $>1$ hospital. P values are based on the chi-square test of the differences between average predicted probabilities of offering services $1988-2000$ by hospital type. (FP v other: $\mathrm{P}<0.01$ (1994-1997)).

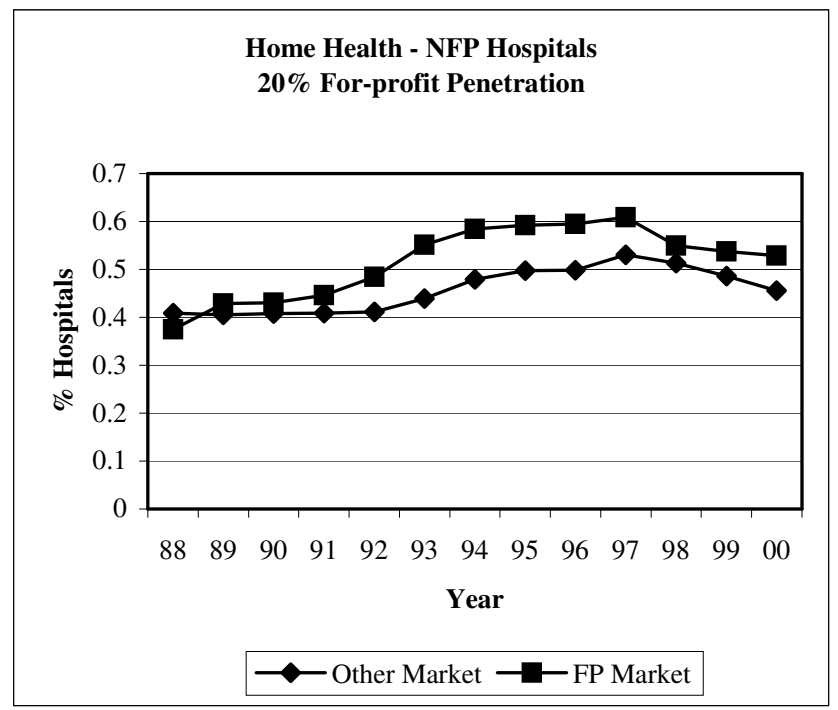

NOTES: Probit predicted probabilities include all general and surgical, non-rural hospitals in MSAs $>1$ hospital. $\mathrm{P}$ values are based on the chi-square test of the differences between average predicted probabilities of offering services $1988-2000$ by hospital type. (FP v other: $\mathrm{P}<0.05)$.

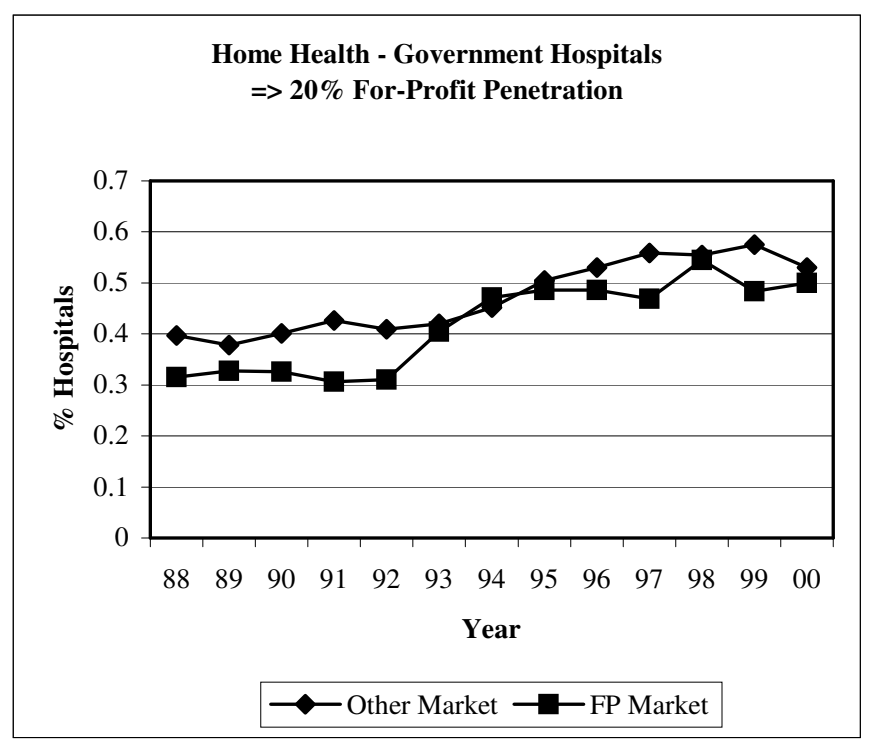

NOTES: Probit predicted probabilities include all general and surgical, non-rural hospitals in MSAs $>1$ hospital. $\mathrm{P}$ values are based on the chi-square test of the differences between average predicted probabilities of offering services 1988 - 2000 by hospital type. (FP v other: not significant). 
Figure 8. Psychiatric Emergency, Market Penetration

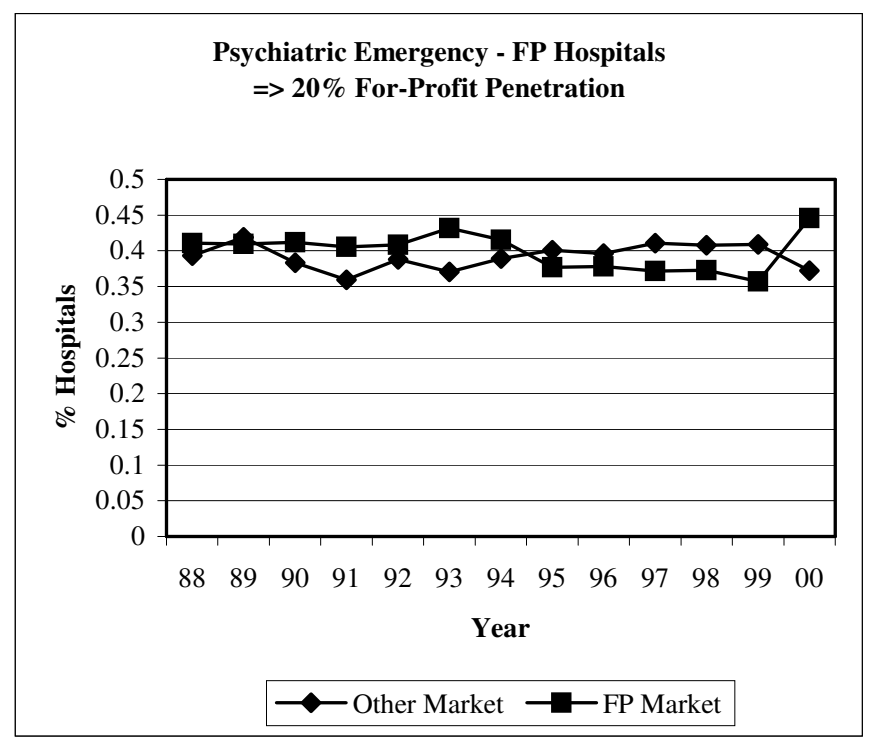

NOTES: Probit predicted probabilities include all general and surgical, non-rural hospitals in MSAs $>1$ hospital. P values are based on the chi-square test of the differences between average predicted probabilities of offering services $1988-2000$ by hospital type. (FP v other: not significant).

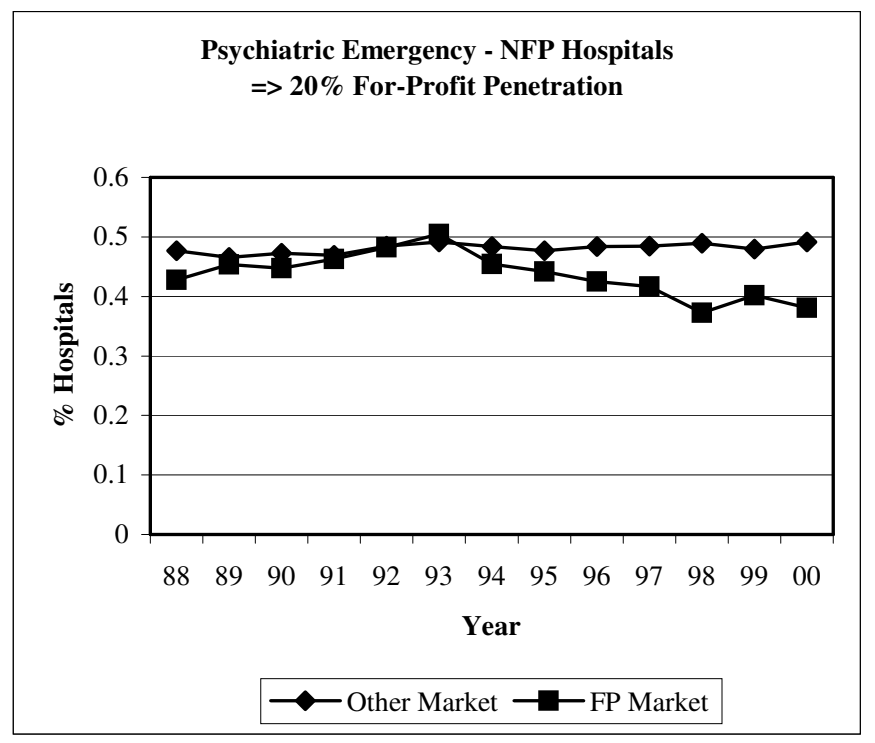

NOTES: Probit predicted probabilities include all general and surgical, non-rural hospitals in MSAs $>1$ hospital. P values are based on the chi-square test of the differences between average predicted probabilities of offering services $1988-2000$ by hospital type. (FP v other: $\mathrm{P}<010)$.

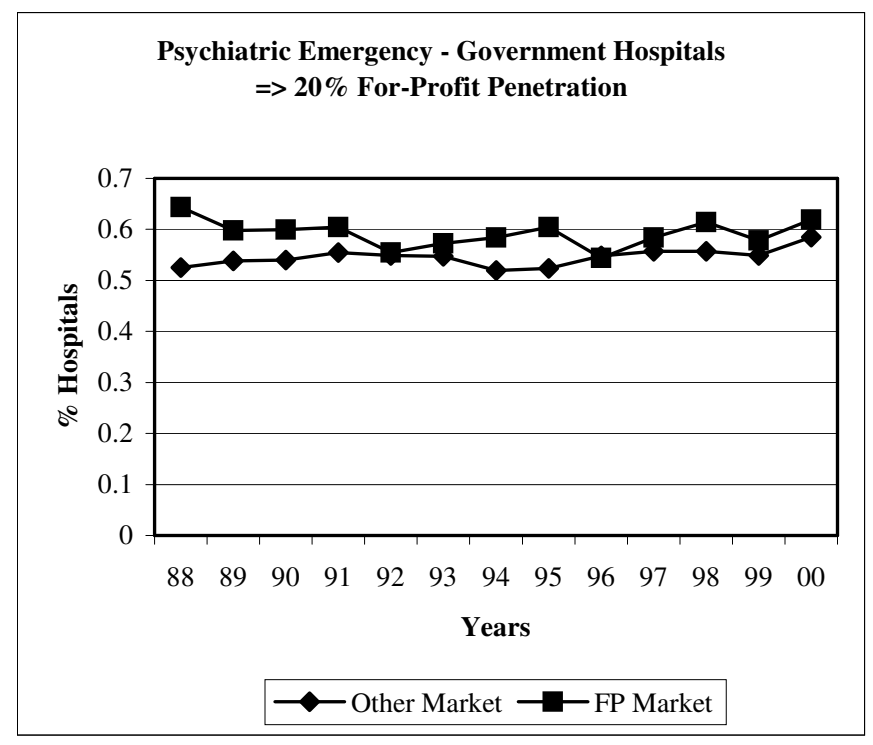

and surgical, non-rural hospitals in MSAs $>1$ hospital. $\mathrm{P}$ values are based on the chi-square test of the differences between average predicted probabilities of offering services $1988-2000$ by hospital type. (FP v other: not significant). 
Table 8. Hypothesis Test for Market Effects Tests

\begin{tabular}{|c|c|c|c|}
\hline \multirow[b]{2}{*}{\begin{tabular}{|c|} 
Service \\
\end{tabular}} & \multicolumn{3}{|c|}{ FP Market $>=20 \%$ Share } \\
\hline & Other & FP $20 \%$ & Chi2/Pr $>\mathrm{Chi}^{\wedge} 2$ \\
\hline \multicolumn{4}{|l|}{ Open Heart Surgery } \\
\hline \multirow[t]{2}{*}{ NFP Hospitals } & 0.32 & 0.374 & 5.045 \\
\hline & & & 0.025 \\
\hline \multirow[t]{2}{*}{ Gov Hospitals } & 0.255 & 0.347 & 7.313 \\
\hline & & & 0.007 \\
\hline \multirow[t]{2}{*}{ FP Hospitals } & 0.391 & 0.431 & 1.39 \\
\hline & & & 0.239 \\
\hline & & & \\
\hline \multicolumn{4}{|l|}{ Psychiatric ER } \\
\hline \multirow[t]{2}{*}{ NFP Hospitals } & 0.481 & 0.436 & 3.262 \\
\hline & & & 0.071 \\
\hline \multirow[t]{2}{*}{$88-93$} & 0.477 & 0.463 & 0.216 \\
\hline & & & 0.642 \\
\hline \multirow[t]{2}{*}{$94-00$} & 0.484 & 0.413 & 18.119 \\
\hline & & & 0.011 \\
\hline \multirow[t]{2}{*}{ Gov Hospitals } & 0.546 & 0.592 & 1.641 \\
\hline & & & 0.200 \\
\hline \multirow[t]{2}{*}{ FP Hospitals } & 0.392 & 0.4 & 0.044 \\
\hline & & & 0.835 \\
\hline \multicolumn{4}{|l|}{ Home Health } \\
\hline \multirow[t]{2}{*}{ NFP Hospitals } & 0.457 & 0.516 & 4.119 \\
\hline & & & 0.042 \\
\hline \multirow[t]{2}{*}{ Gov Hospitals } & 0.472 & 0.418 & 1.233 \\
\hline & & & 0.267 \\
\hline \multirow[t]{2}{*}{ FP Hospitals } & 0.326 & 0.333 & 0.009 \\
\hline & & & 0.923 \\
\hline \multirow[t]{2}{*}{$88-93$} & 0.231 & 0.188 & 1.673 \\
\hline & & & 0.196 \\
\hline \multirow[t]{2}{*}{$94-97$} & 0.5 & 0.613 & 8.089 \\
\hline & & & 0.004 \\
\hline
\end{tabular}


Appendix A. Selected Probit Coefficients for Representative Services (controlling for hospital, region, and demographic characteristics)

\begin{tabular}{|c|c|c|c|c|c|c|}
\hline Service & \multicolumn{2}{|c|}{ Open Heart Surgery } & \multicolumn{2}{|c|}{ Psychiatric ER } & \multicolumn{2}{|c|}{ Home Health } \\
\hline Observations & \multicolumn{2}{|c|}{32231} & \multicolumn{2}{|c|}{32058} & \multicolumn{2}{|c|}{31980} \\
\hline \multirow[t]{2}{*}{\begin{tabular}{|l|} 
Log Likelihood \\
\end{tabular}} & \multicolumn{2}{|c|}{-11667.26} & \multicolumn{2}{|c|}{-18060.59} & \multicolumn{2}{|c|}{-19975.22} \\
\hline & \begin{tabular}{l|} 
Coef. \\
\end{tabular} & Std. Err. & Coef. & Std. Err. & Coef. & Std. Err. \\
\hline Gov & -0.420 & 0.098 & 0.247 & 0.070 & -0.077 & 0.068 \\
\hline $\mathrm{Fp}$ & 0.397 & 0.100 & -0.172 & 0.082 & -0.745 & 0.088 \\
\hline y1989 & 0.040 & 0.020 & -0.019 & 0.021 & 0.010 & 0.019 \\
\hline y1990 & 0.116 & 0.023 & -0.003 & 0.026 & 0.016 & 0.023 \\
\hline y1991 & 0.198 & 0.028 & -0.007 & 0.028 & 0.024 & 0.026 \\
\hline y1992 & 0.240 & 0.030 & 0.038 & 0.031 & 0.031 & 0.028 \\
\hline y1993 & 0.315 & 0.034 & 0.065 & 0.033 & 0.119 & 0.029 \\
\hline $\mathrm{y} 1994$ & 0.336 & 0.037 & 0.027 & 0.036 & 0.223 & 0.034 \\
\hline $\mathrm{y} 1995$ & 0.330 & 0.038 & 0.001 & 0.037 & 0.279 & 0.035 \\
\hline y1996 & 0.330 & 0.040 & 0.008 & 0.038 & 0.289 & 0.037 \\
\hline y1997 & 0.352 & 0.043 & 0.003 & 0.040 & 0.365 & 0.038 \\
\hline y1998 & 0.343 & 0.045 & 0.005 & 0.040 & 0.299 & 0.039 \\
\hline y1999 & 0.453 & 0.046 & -0.012 & 0.040 & 0.235 & 0.039 \\
\hline y2000 & 0.436 & 0.047 & 0.016 & 0.041 & 0.160 & 0.040 \\
\hline govy1989 & 0.085 & 0.053 & 0.020 & 0.050 & -0.044 & 0.038 \\
\hline govy1990 & 0.100 & 0.061 & 0.011 & 0.057 & -0.002 & 0.045 \\
\hline govy1991 & 0.146 & 0.067 & 0.055 & 0.062 & 0.034 & 0.052 \\
\hline govy1992 & 0.116 & 0.071 & -0.039 & 0.069 & -0.001 & 0.055 \\
\hline govy1993 & 0.130 & 0.084 & -0.056 & 0.073 & -0.024 & 0.058 \\
\hline govy1994 & 0.164 & 0.089 & -0.077 & 0.078 & -0.021 & 0.068 \\
\hline govy1995 & 0.156 & 0.090 & -0.022 & 0.081 & 0.040 & 0.071 \\
\hline govy1996 & 0.190 & 0.091 & -0.014 & 0.085 & 0.081 & 0.076 \\
\hline govy1997 & 0.090 & 0.102 & 0.044 & 0.090 & 0.050 & 0.081 \\
\hline govy1998 & 0.131 & 0.105 & 0.062 & 0.093 & 0.163 & 0.085 \\
\hline govy1999 & 0.070 & 0.108 & 0.042 & 0.093 & 0.206 & 0.086 \\
\hline govy2000 & 0.242 & 0.108 & 0.125 & 0.093 & 0.216 & 0.088 \\
\hline fpy1989 & 0.003 & 0.050 & 0.046 & 0.059 & -0.003 & 0.062 \\
\hline fpy1990 & -0.042 & 0.062 & -0.007 & 0.071 & 0.014 & 0.072 \\
\hline fpy1991 & -0.076 & 0.069 & -0.038 & 0.080 & -0.019 & 0.084 \\
\hline fpy1992 & -0.055 & 0.082 & -0.055 & 0.089 & 0.125 & 0.092 \\
\hline fpy1993 & -0.056 & 0.087 & -0.061 & 0.092 & 0.325 & 0.093 \\
\hline fpy1994 & -0.015 & 0.091 & -0.033 & 0.096 & 0.748 & 0.100 \\
\hline fpy1995 & -0.047 & 0.095 & -0.066 & 0.098 & 0.923 & 0.102 \\
\hline fpy1996 & -0.051 & 0.102 & -0.077 & 0.101 & 0.992 & 0.108 \\
\hline fpy1997 & -0.058 & 0.106 & -0.070 & 0.103 & 0.882 & 0.108 \\
\hline fpy1998 & -0.011 & 0.109 & -0.073 & 0.105 & 0.242 & 0.111 \\
\hline \begin{tabular}{|l|} 
fpy1999 \\
\end{tabular} & -0.088 & 0.116 & -0.094 & 0.110 & -0.034 & 0.114 \\
\hline fpy2000 & -0.013 & 0.111 & 0.036 & 0.103 & 0.014 & 0.114 \\
\hline Cons & 8.364 & 5.493 & 0.077 & 3.992 & 6.350 & 3.846 \\
\hline
\end{tabular}

Robust standard errors. 
Appendix A (cont). Selected Probit Coefficients for Representative Services (controlling for hospital, region, and demographic characteristics)

\begin{tabular}{|l|r|r|r|r|}
\hline Service & \multicolumn{2}{|c|}{ MRI } & \multicolumn{2}{c|}{ ESWL } \\
\hline Observations & \multicolumn{2}{|c|}{31972} & \multicolumn{2}{|c|}{$\mathbf{3 2 1 1 8}$} \\
\hline Log Likelihood & \multicolumn{2}{|c|}{$\mathbf{- 1 6 9 6 4 . 8 0}$} & \multicolumn{2}{|c|}{$\mathbf{1 2 1 4 5 . 1 5}$} \\
\hline & Coef. & \multicolumn{1}{|c|}{ Std. Err. } & \multicolumn{1}{|c|}{ Coef. } & Std. Err. \\
\hline Gov & -0.383 & 0.082 & -0.142 & 0.105 \\
\hline Fp & -0.195 & 0.091 & 0.322 & 0.106 \\
\hline y1989 & 0.120 & 0.025 & 0.161 & 0.035 \\
\hline y1990 & 0.241 & 0.033 & 0.156 & 0.043 \\
\hline y1991 & 0.356 & 0.036 & 0.277 & 0.046 \\
\hline y1992 & 0.514 & 0.039 & 0.356 & 0.048 \\
\hline y1993 & 0.697 & 0.041 & 0.491 & 0.050 \\
\hline y1994 & 0.989 & 0.043 & 0.578 & 0.050 \\
\hline y1995 & 1.107 & 0.044 & 0.633 & 0.051 \\
\hline y1996 & 1.172 & 0.046 & 0.648 & 0.053 \\
\hline y1997 & 1.221 & 0.047 & 0.704 & 0.054 \\
\hline y1998 & 1.288 & 0.048 & 0.736 & 0.056 \\
\hline y1999 & 1.397 & 0.049 & 0.830 & 0.055 \\
\hline y2000 & -4.802 & 3.504 & -2.536 & 4.133 \\
\hline govy1989 & 1.438 & 0.048 & 0.954 & 0.055 \\
\hline govy1990 & 0.057 & 0.059 & 0.022 & 0.078 \\
\hline govy1991 & 0.117 & 0.075 & 0.037 & 0.097 \\
\hline govy1992 & 0.176 & 0.080 & 0.003 & 0.107 \\
\hline govy1993 & 0.181 & 0.085 & -0.060 & 0.112 \\
\hline govy1994 & 0.166 & 0.091 & 0.031 & 0.117 \\
\hline govy1995 & 0.088 & 0.097 & -0.092 & 0.123 \\
\hline govy1996 & 0.051 & 0.097 & -0.187 & 0.126 \\
\hline govy1997 & 0.066 & 0.100 & -0.153 & 0.126 \\
\hline govy1998 & 0.139 & 0.104 & -0.138 & 0.131 \\
\hline govy1999 & 0.215 & 0.108 & -0.009 & 0.132 \\
\hline govy2000 & 0.196 & 0.108 & -0.032 & 0.130 \\
\hline fpy1989 & 0.256 & 0.109 & -0.025 & 0.131 \\
\hline fpy1990 & 0.031 & 0.077 & -0.090 & 0.072 \\
\hline fpy1991 & 0.159 & 0.095 & -0.105 & 0.101 \\
\hline fpy1992 & 0.184 & 0.103 & -0.078 & 0.112 \\
\hline fpy1993 & 0.109 & 0.108 & -0.146 & 0.119 \\
\hline fpy1994 & 0.105 & -0.117 & 0.123 \\
\hline fpy1995 & 0.112 & -0.037 & 0.121 \\
\hline fpy1996 & 0.114 & -0.007 & 0.123 \\
\hline fpy1997 & 0.116 & -0.119 & 0.126 \\
\hline fpy1999 & 0.178 & 0.122 \\
\hline fons & 0.142 & 0.127 \\
\hline
\end{tabular}

Robust standard errors. 
Appendix B. Selected Probit Coefficients, Market Effects Tests

Controlling for hospital, region, and demographic characteristics; excluded category is NFP hospitals in 1994.

\begin{tabular}{|c|c|c|c|c|c|c|}
\hline Service & \multicolumn{2}{|c|}{ Open Heart Surgery } & \multicolumn{2}{|c|}{ Home Health } & \multicolumn{2}{|c|}{ Psychiatric ER } \\
\hline $\begin{array}{l}\text { Log Likelihood } \\
\text { No. of Obs. }\end{array}$ & $\begin{array}{c}-11816.168 \\
32231\end{array}$ & & $\begin{array}{c}-19961.012 \\
31980\end{array}$ & & $\begin{array}{c}-18084.506 \\
32058\end{array}$ & \\
\hline Variables & Coef. & Std. Err. & Coef. & Std. Err. & Coef. & Std. Err. \\
\hline NFP*1988 & -.390 & .0358 & -.187 & .0351 & -.0212 & .0383 \\
\hline NFP*1989 & -.334 & .0355 & -.198 & .0346 & -.0548 & .0371 \\
\hline NFP*1990 & -.258 & .0318 & -.191 & .0348 & -.0338 & .0357 \\
\hline NFP*1991 & -.181 & .0308 & -.188 & .0339 & -.0440 & .0332 \\
\hline NFP*1992 & -.104 & .0227 & -.181 & .0316 & .00258 & .0319 \\
\hline NFP*1993 & -.0172 & .0206 & -.107 & .0271 & .0247 & .0310 \\
\hline NFP*1995 & -.0231 & .0255 & .0485 & .0201 & -.0195 & .0215 \\
\hline NFP*1996 & -.0185 & .0312 & .0528 & .0265 & .00199 & .0292 \\
\hline NFP*1997 & .0163 & .0371 & .137 & .0317 & .00264 & .0329 \\
\hline NFP*1998 & .0260 & .0354 & .0912 & .0354 & .0176 & .0379 \\
\hline NFP*1999 & .155 & .0449 & .0187 & .0369 & -.0111 & .0341 \\
\hline NFP $* 2000$ & .123 & .0450 & -.0608 & .0451 & .0244 & .0386 \\
\hline GOV*1988 & -.808 & .131 & -.221 & .0720 & .128 & .0838 \\
\hline GOV*1989 & -.640 & .131 & -.273 & .0718 & .168 & .0848 \\
\hline GOV*1990 & -.628 & .131 & -.209 & .0750 & .172 & .0827 \\
\hline GOV*1991 & -.496 & .131 & -.140 & .0776 & .218 & .0811 \\
\hline GOV*1992 & -.447 & .127 & -.186 & .0751 & .201 & .0858 \\
\hline $\mathrm{GOV}^{*} 1993$ & -.388 & .134 & -.159 & .0774 & .196 & .0846 \\
\hline GOV*1994 & -.306 & .132 & -.0731 & .0858 & .111 & .0825 \\
\hline GOV*1995 & -.328 & .137 & .0683 & .0855 & .122 & .0810 \\
\hline GOV*1996 & -.295 & .137 & .136 & .0955 & .199 & .0900 \\
\hline GOV*1997 & -.355 & .144 & .213 & .107 & .227 & .0951 \\
\hline GOV*1998 & -.346 & .137 & .201 & .107 & .227 & .107 \\
\hline GOV*1999 & -.246 & .146 & .257 & .101 & .201 & .106 \\
\hline $\mathrm{GOV} * 2000$ & -.111 & .137 & .135 & .104 & .312 & .103 \\
\hline $\mathrm{FP} * 1988$ & .105 & .145 & -.767 & .129 & -.278 & .148 \\
\hline FP*1989 & .0866 & .152 & -.814 & .131 & -.198 & .119 \\
\hline FP*1990 & .0723 & .147 & -.772 & .115 & -.310 & .126 \\
\hline FP*1991 & -.0517 & .163 & -.770 & .130 & -.387 & .135 \\
\hline FP*1992 & .216 & .133 & -.786 & .113 & -.296 & .116 \\
\hline FP*1993 & .253 & .152 & -.450 & .114 & -.352 & .129 \\
\hline FP*1994 & .357 & .135 & -.238 & .103 & -.292 & .110 \\
\hline FP*1995 & .366 & .155 & .0969 & .117 & -.255 & .128 \\
\hline FP*1996 & .314 & .156 & .178 & .127 & -.270 & .116 \\
\hline FP*1997 & .284 & .165 & .187 & .100 & -.224 & .142 \\
\hline FP*1998 & .488 & .124 & -.355 & .102 & -.232 & .179 \\
\hline FP*1999 & .498 & .168 & -.583 & .142 & -.230 & .162 \\
\hline $\mathrm{FP} * 2000$ & .546 & .161 & -.729 & .142 & -.346 & .143 \\
\hline NFP*FPMarket*1988 & .113 & .159 & -.282 & .102 & -.172 & .105 \\
\hline NFP*FPMarket*1989 & .0969 & .146 & -.134 & .0962 & -.0917 & .124 \\
\hline NFP*FPMarket*1990 & .171 & .139 & -.130 & .0976 & -.110 & .101 \\
\hline NFP*FPMarket*1991 & .259 & .145 & -.0871 & .0975 & -.0641 & .0946 \\
\hline NFP*FPMarket*1992 & .336 & .178 & .0143 & .140 & -.00320 & .101 \\
\hline NFP*FPMarket*1993 & .246 & .153 & .192 & .128 & .0644 & .103 \\
\hline NFP*FPMarket*1994 & .306 & .164 & .281 & .122 & -.0892 & .128 \\
\hline NFP*FPMarket*1995 & .262 & .125 & .303 & .102 & -.127 & .102 \\
\hline NFP*FPMarket*1996 & .214 & .117 & .310 & .0859 & -.179 & .0893 \\
\hline NFP*FPMarket*1997 & .171 & .110 & .347 & .106 & -.207 & .103 \\
\hline NFP*FPMarket*1998 & .0811 & .132 & .187 & .105 & -.344 & .0982 \\
\hline NFP*FPMarket*1999 & .0899 & .115 & .155 & .0942 & -.251 & .0981 \\
\hline NFP*FPMarket*2000 & .144 & .132 & .133 & .125 & -.317 & .102 \\
\hline GOV*FPMarket*1988 & -.324 & .207 & -.452 & .162 & .500 & .150 \\
\hline GOV*FPMarket*1989 & -.333 & .243 & -.416 & .155 & .352 & .144 \\
\hline GOV*FPMarket*1990 & -.00551 & .208 & -.422 & .146 & .358 & .133 \\
\hline GOV*FPMarket*1991 & .125 & .185 & -.480 & .153 & .373 & .132 \\
\hline GOV*FPMarket*1992 & .126 & .219 & -.468 & .174 & .217 & .158 \\
\hline GOV*FPMarket*1993 & .277 & .210 & -.201 & .176 & .274 & .138 \\
\hline
\end{tabular}




\section{Appendix B (cont). Selected Probit Coefficients, Market Effects Tests}

\begin{tabular}{|l|c|c|c|c|c|c|}
\hline GOV*FPMarket*1994 & .246 & .217 & -.0196 & .177 & .310 & .165 \\
\hline GOV*FPMarket*1995 & .186 & .262 & .0187 & .178 & .373 & .150 \\
\hline GOV*FPMarket*1996 & .137 & .224 & .0197 & .168 & .186 & .129 \\
\hline GOV*FPMarket*1997 & .0217 & .234 & -.0270 & .180 & .311 & .139 \\
\hline GOV*FPMarket*1998 & .123 & .222 & .176 & .182 & .406 & .158 \\
\hline GOV*FPMarket*1999 & -.00914 & .197 & .0113 & .153 & .291 & .121 \\
\hline GOV*FPMarket*2000 & .207 & .183 & .0563 & .158 & .420 & .143 \\
\hline FP*FPMarket*1988 & .170 & .144 & -1.04 & .120 & -.225 & .108 \\
\hline FP*FPMarket*1989 & .252 & .163 & -1.00 & .136 & -.228 & .130 \\
\hline FP*FPMarket*1990 & .308 & .154 & -.987 & .128 & -.220 & .138 \\
\hline FP*FPMarket*1991 & .407 & .146 & -1.03 & .122 & -.241 & .152 \\
\hline FP*FPMarket*1992 & .458 & .159 & -.778 & .127 & -.231 & .141 \\
\hline FP*FPMarket*1993 & .547 & .170 & -.524 & .116 & -.159 & .137 \\
\hline FP*FPMarket*1994 & .584 & .170 & .264 & .104 & -.210 & .134 \\
\hline FP*FPMarket*1995 & .494 & .133 & .367 & .125 & -.330 & .124 \\
\hline FP*FPMarket*1996 & .514 & .134 & .436 & .116 & -.328 & .107 \\
\hline FP*FPMarket*1997 & .556 & .134 & .378 & .111 & -.348 & .105 \\
\hline FP*FPMarket*1998 & .514 & .158 & -.413 & .0934 & -.345 & .104 \\
\hline FP*FPMarket*1999 & .554 & .142 & -.800 & .0914 & -.394 & .114 \\
\hline FP*FPMarket*2000 & .609 & .154 & -.780 & .101 & -.116 & .104 \\
\hline
\end{tabular}

